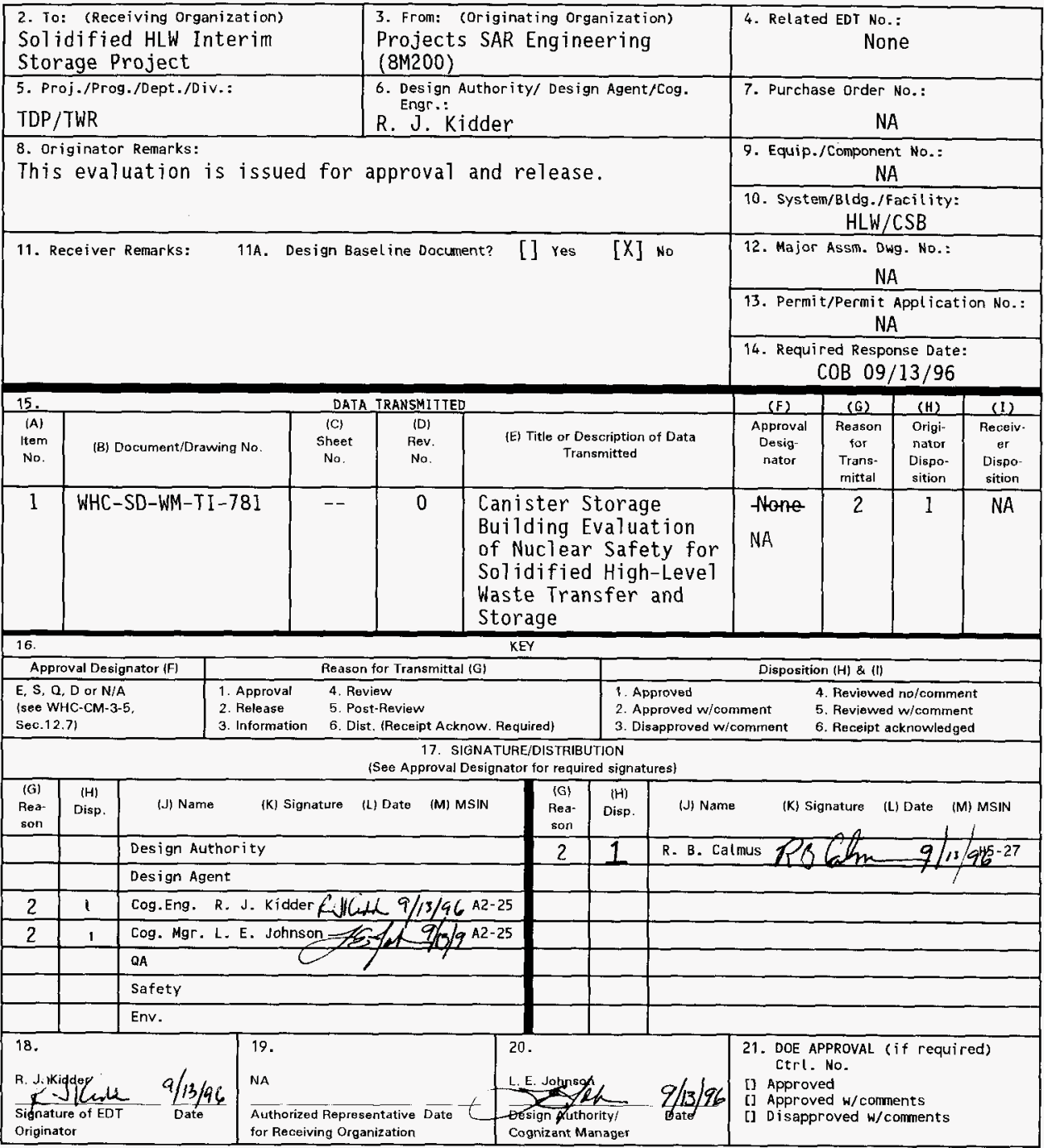




\section{Canister Storage Building Evaluation of Nuclear Safety for Solidified High-Level Waste Transfer and Storage}

R. J. Kidder

Westinghouse Hanford Company, Richland, WA 99352

U.S. Department of Energy Contract DE-AC06-87RL10930

$\begin{array}{ll}\text { EDT/ECN: } 616269 & \text { UC: UC230 } \\ \text { Org Code: } 8 \text { M200 } & \text { Charge Code: } \text { D4NB7 } \\ \text { B\&R Code: EW3130010 } & \text { Total Pages: } 55\end{array}$

Key Words: Canister Storage, High-Level Waste, Safety Evaluation

Abstract: This document is issued to evaluate the safety impacts to the Canister Storage Building from transfer and storage of solidified highlevel waste.

TRADEMARK DISCLAIMER. Reference herein to any specific commercial product, process, or service by trade name, trademark, manufacturer, or otherwise, does not necessarily constitute or imply its endorsement, recommendation, or favoring by the United States Government or any agency thereof or its contractors or subcontractors.

Printed in the United States of America. To obtain copies of this document, contact: WHC/BCS Document Control Services, P.O. Box 1970, Mailstop H6-08, Richland WA 99352, Phone (509) 372-2420; Fax (509) 376-4989.
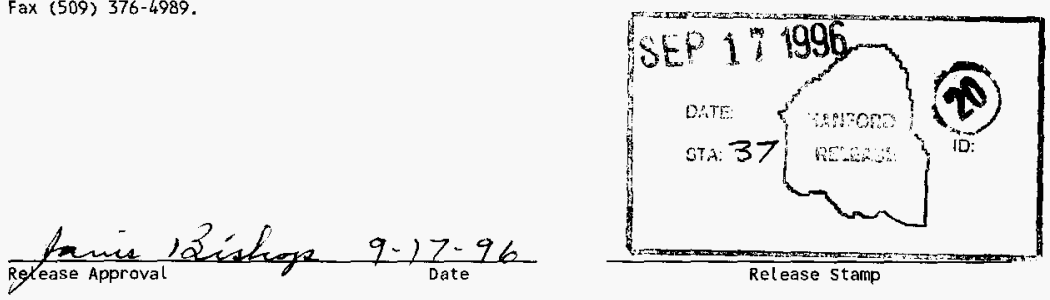

\section{Approved for Public Release}


WHC-SD-WM-TI-781, Rev. 0

CANISTER STORAGE BUILDING EVALUATION OF NUCLEAR SAFETY

FOR SOLIDIFIED HIGH-LEVEL WASTE TRANSFER AND STORAGE

SEPTEMBER 1996

Prepared by: R. J. Kidder 
WHC-SD-WM-TI-781, Rev. O

\section{EXECUTIVE SUMMARY}

This report provides support for a Westinghouse Hanford Company (WHC) scoping evaluation to identify significant issues for use of the Canister Storage Building (CSB) for interim storage of solidified high-level waste (HLW) produced during the Phase I privatization effort. The waste forms evaluated were glass canisters (large and smal1) and containers of loaded cesium ion exchange resin.

To identify bounding accident scenarios, several safety analyses and evaluations and some draft operating manuals for spent nuclear fuel (SNF) handing in the CSB were reviewed. Potential abnormal occurrences which could cause a release of radioactive material from either or both of the container types that could challenge the CSB safety systems was developed. The abnormal occurrences was classified by types (accident phenomena) and were combined to form accident analyses for the bounding releases from each type of accident. From these bounding analyses, preliminary lists of safety class and significant systems for the CSB were developed. Detailed structural or thermal analyses were not performed when analysis information was not available, or loss of confinement was assumed for containers and/or CSB components when subjected to abnormal thermal or mechanical stresses. The preliminary conclusion was that no additional engineered safety features would be required for interim storage of SNF.

The effect of the storage of $H \mathrm{LW}$ in the CSB on the hazard category of the CSB was to continue to classify the building as Hazard Category 2. A single HLW container (glass canister or cesium container per the inventory information provided by $W H C$ ) has sufficient radionuclide inventory to result in a Hazard Category 2 per DOE-STD-1027-92. Designating the CSB a Category 1 facility is a decision that could be made by the Program Secretarial officer (PSO).

A qualitative evaluation was performed to determine if the cesium container should be double or single contained. Based on current design information and assumptions, the improvement in residual risk provided by the secondary cesium container would be relatively small.

This evaluation did not find any additional Nuclear Regulatory Commission (NRC) requirements beyond the present SNF Project requirements but a recommended future detailed NRC equivalency review may provide additional requirements.

It is recommended that for future safety analysis, during conceptual design, a formal hazards identification/evaluation should be performed of the entire HLW container handling and storage process. Verification and validation of the inventory assumptions (radionuclide content and physical form) used for accident analysis should be performed. This is particularly important for the physical form of the cesium ion exchange resin. If the resin is grounded or somehow reduced to small particles during the drying process, this will potentially change the accident analysis results. The safety equipment list should be verified, to make sure that the appropriate 
CSB systems are incorporated. A structural analysis should be performed to determine the potential effects of dropping a new multicanister overpack handling machine (MHM) cask on the safety-class vault roof, either during construction or a seismic event. A pre] iminary hazard categorization must be documented. Because the design of the facility and process is in a relatively early stage, no attempt was made to evaluate accident frequencies. To

evaluate risk, some sort of frequency determination will need to be performed. A set of administrative controls and Technical Safety Requirements/Operational Safety Requirements (TSR/OSR) must be developed to assure that the assumptions in the safety analysis are implemented in the design and operation of the facility. In particular, the appropriate surveillance program for containers in interim storage must be developed. This report assumes that some periodic monitoring of the storage tubes will be performed by a surveillance program. 


\section{CONTENTS}

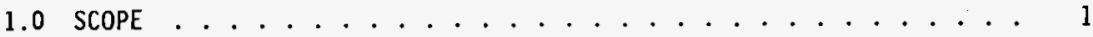

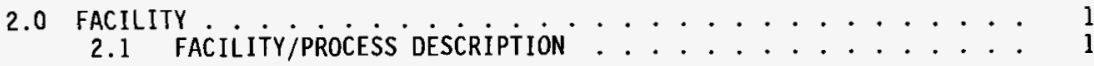

3.0 INVENTORY
3.1 RADIONUCLIDE INVENTORIES

3.1.1 Glass Canisters.................. 6

3.1 .2 Cesium Ion Exchange Resin Containers (Cesium
Containers) ................. 6

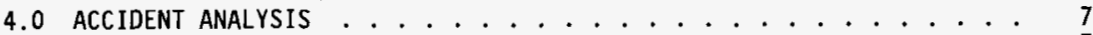

4.1 CSB STORAGE HAZARDS .................... 7

4.1.1 Abnormal Dccurrences During CSB Storage . . . . . . . 7

4.1.2 RESULTS/DISCUSSION OF CSB STORAGE .......... 10

4.1.3 Accidents for Further Analys is . . . . . . . . . . . . 11

4.2 CONSEQUENCES OF ACCIDENTS .............. 12

4.2.1 Consequence Analysis ............... 12

4.2.2 Radionuclide Inventories ............. . . 14

4.2.3 Accident Scenarios ............... . 14

4.3 SAFETY CLASSIFICATION SUMMARY .............. 3 . . .

5.0 HAZARD CLASSIFICATION EVALUATION . . . . . . . . . . . . . 34

6.0 CESIUM CONTAINER EVALUATION . . . . . . . . . . . . . . . . 37

6.1 CONTAINER TRANSPORTATION ........................ 37

6.2 CONTAINER STORAGE .................. 38

6.2.1 Mechanical Damage ............... . 38

6.2 .2 Corrosion ................ . . 39

6.2.3 Pressurization .............. . . 39

6.2 .4 0verheating ................. 40

6.2 .5 Explosion................ 40

6.2 .6 Summary.................. 41

7.0 NRC EQUIVALENCY REVIEW . . . . . . . . . . . . . . . . 42

7.1 DESIGN AND CONSTRUCTION MEASURES ............. . 42

7.1.1 Results..................... 43

7.2 CONCLUSIONS . . . . . . . . . . . . . . . 43

8.0 SAFETY ANALYSIS REQUIREMENTS . . . . . . . . . . . . . . . . 44

9.0 REFERENCES ....................... . . . 46 


\section{LIST OF TABLES}

3-1. Glass Properties. ................. 3

3-2. Radionuclide Composition of Glass ............. 3

3-3. Cessium-Loaded Ion Exchange Resin Properties . . . . . . . . 5

3-4. Radionuclide Compositions in Undiluted Supernate IX Column Feed. .............. 5

4-1. Postulated Abnormal Occurrences During CSB Receiving and Storage (2 Sheets)............ 8

4-2. Atmospheric Dispersion Coefficients Used in Accident Analyses for the CSB . . . . . . . . . 13

4-3. Unmitigated Dose Consequences for a Dropped Glass Canister Onto Another Canister. . . . . . . . . . 16

4-4. Mitigated Dose Consequences for a Dropped Glass Canister Onto Another Canister. . . . . . . . . . . . 17

4-5. Unmitigated Dose Consequences for a Dropped G1ass Canister. ................... 20

4-6. Mitigated Dose Consequences for a Dropped Glass Canister. . . . . . . . . . . . . 21

4-7. Unmitigated Dose Consequences for Glass Canister Over-Pressurization. . . . . . . . . . . . . 23

4-8. Unmitigated Dose Consequences for a Dropped Cesium Container. . . . . . . . . . . . . . . 26

4-9. Mitigated Dose Consequences for a Dropped Glass Canister. . . . . . . . . . . . . 27

4-10. Unmitigated Dose Consequences for a Pressurized Release from a Cesium Container. . . . . . . . . . 30

4-11. Mitigated Dose Consequences for a Pressurized Release from a Canister. . . . . . . . . . . . 31

4-12. Safety Systems, Structures, and Components

4-13. Priteria. (2 sheets) Safety-Significant SSCs. . . . . . . . . . . . . 34

5-1. Preliminary Hazard Categorization For One Large Glass Canister. (2 sheets) .............. 35

$6-1$. Summary of Double Containment Evaluation. . . . . . .

8-1. Resources and Schedule......................... 45 
WHC-SD-WM-TI-781, Rev. 0

\section{LIST OF ACRONYMS}

$\begin{array}{ll}\text { ARF } & \text { airborne release fraction } \\ \text { CSB } & \text { Canister Storage Building } \\ \text { DOE } & \text { U.S. Department of Energy } \\ \text { EDE } & \text { effective dose equivalent } \\ \text { HLW } & \text { high level waste } \\ \text { HWVP } & \text { Hanford Waste Vitrification Plant } \\ \text { MCO } & \text { multi-canister overpacks } \\ \text { MHM } & \text { multi-canister overpack handling machine } \\ \text { NRC } & \text { Nuclear Regulatory Commission } \\ \text { PSAR } & \text { Preliminary Safety Analysis Report } \\ \text { PSO } & \text { Program Secretarial Officer } \\ \text { RF } & \text { respirable fraction } \\ \text { RFP } & \text { request for proposal } \\ \text { SNF } & \text { spent nuclear fuel } \\ \text { SSC } & \text { systems, structures, and components } \\ \text { TQ } & \text { threshold quantity } \\ \text { TSR/0SR } & \text { Technical Safety Requirement/Operational Safety Analysis Report } \\ \text { WHC } & \text { Westinghouse Hanford Company }\end{array}$


WHC-SD-WM-TI-781, Rev. 0

This page intentionally left blank. 


\subsection{SCOPE}

This evaluation identifies nuclear safety issues and formulates preliminary findings. This report evaluates whether the Canister Storage Building (CSB), as designed for SNF storage, can provide for the safe storage of solidified high-level waste (HLW) in accordance with all applicable U.S. Department of Energy (DOE) guidance documents.

\subsection{FACILITY}

The path forward for solidified HLW interim storage is affected by whether the SNF CSB, as designed for storage, can provide for the safe storage of solidified HLW (WHC 1996). This entails the use of the CSB for interim storage of solidified HLW produced during the Phase I privatization effort. An initial engineering assessment indicated that excess CSB vaults (two southern most) could, with some modification, be used for immobilized HLW interim storage (Jacobs 1996). However, this engineering evaluation included only a cursory assessment of safety impacts on CSB design and operation.

Solidified HLW encompasses canisters containing vitrified (glass) HLW and containers containing cesium separated from waste by ion exchange into resin during low-level waste pretreatment. The vitrified HLW canisters may be either standard size or elongated. Standard canisters, large canisters, and cesium containers physical characteristics are presented in Section 3.1.

For purposes of the evaluation basis, the canister/container should be assumed to provide primary containment. The canister/container are stainless steel with a welded leak-tight closure. The fraction of waste matrix (HLW glass or cesium) that could yield respirable fines under accident scenarios is unknown. Standard assumptions regarding respirable fraction (RF) were adopted for the evaluation basis.

\subsection{FACILITY/PROCESS DESCRIPTION}

The CSB interim storage facility was designed and partially constructed for vitrified waste interim storage to immobilize HLW at the Hanford Waste Vitrification Plant (HWVP). Construction of the CSB was halted in 1993 after cancellation of the HWVP Project, with only the concrete pad and a wall section built. Removal of SNF from the K Basins and other Hanford SNF storage locations became a Site priority, and an interim storage facility was needed. The CSB was subsequently re-scoped to accommodate Hanford Site SNF interim storage. Construction of the CSB was restarted in Apri1, 1996. Although only one of the three vaults is required for SNF interim storage, the SNF project plans to construct all three vaults, including structural components and decking. Storage tubes and exhaust stacks will not be provided for the two excess vaults, but will be provided if necessary for waste immobilization. 
WHC-SD-WM-TI-781, Rev. 0

The CSB design includes three below-grade vaults approximately $50 \mathrm{~m}$ wide by $55 \mathrm{~m}$ long by $14 \mathrm{~m}$ deep, with each vault consisting of a matrix of 22 rows by 10 columns for a total of 220 steel storage tubes. Six oversized storage tubes are also provided in each vault to accommodate overpacked canisters. Each tube can hold three canisters, equating to 678 canisters per vault.

Decay heat from the glass canisters and cesium containers will be removed by natural convection. Cooling air is drawn through an inlet duct into a plenum that distributes it into the vault, flows across the tubes, and exits through an elevated exhaust stack. The motive force for drawing cooling air through the vault is natural convection caused by a density difference between hot air inside the vault and stack, relative to cool intake air.

The glass canisters and cesium containers will be transported to the CSB in an onsite transportation cask via a diesel-powered tractor/trailer. The truck vestibule will be an extension of the CSB that provides an air-locked transition area for the transport semi-trailer and the receiving cask crane to unload the glass canister or cesium container cask into the receiving pit. After the transport trailer has been positioned in the truck vestibule, the tractor will be disconnected and removed from the facility. The receiving crane will be used to lift the transport cask containing the glass canister or cesium container off the trailer and lower it into the service pit.

The glass canister or cesium container will be transferred to the storage tube. Movement of the glass canisters or cesium containers within the CSB will be accomplished by the multi-canister overpacks (MCO) handiing machine, and the MHM, whose function is to pick up glass canisters or cesium containers from the service pit in the receiving area of the CSB and transfer them to storage tubes in one of the vaults of the CSB. As required for final disposition, the MHM will be capable of reversing the process and retrieving the glass canisters or cesium containers.

\subsection{INVENTORY}

The exact CSB inventory of HLW canisters and cesium containers is unknown. Three cases are, therefore, provided to bound the possible inventory. These cases are described below.

- Case A (standard canister maximum) - Total per vault loading of 678 standard canisters ( 3 standard canisters per storage tube).

- Case B (large canister maximum) - Total per vault loading of 452 large canisters (2 large canisters per storage tube).

- Case C (cesium container maximum) - Per vault loading of cesium containers could range from 226 (1 cesium container per storage tube) to 1356 ( 6 cesium containers per storage tube). However, the aggregate per storage tube inventory will not exceed $3.18 \times 10^{5} \mathrm{Ci}{ }^{137} \mathrm{Cs}, 3.18 \times 10^{5} \mathrm{Ci}$ 
${ }^{137} \mathrm{~B} \mathrm{Ba}$, and $2.1 \mathrm{Ci}{ }^{135} \mathrm{Cs}$ regardless of the number of containers per storage tube.

Solidified HLW encompasses canisters containing vitrified (glass) HLW (Tables 3-1 and 3-2) and containers of cesium-loaded ion exchange resin generated during low-level waste pretreatment (Tables 3-3 and 3-4).

Table 3-1. Glass Properties.

\begin{tabular}{|l|l|}
\hline \multicolumn{1}{|c|}{ Oxide } & \multicolumn{1}{c|}{ kg Oxide/kg Glass } \\
\hline $\mathrm{SiO}_{2}$ & 0.501 \\
\hline $\mathrm{B}_{2} \mathrm{O}_{3}$ & 0.098 \\
\hline $\mathrm{Na}_{2} \mathrm{O}$ & 0.091 \\
\hline $\mathrm{Li}_{2} \mathrm{O}$ & 0.060 \\
\hline $\mathrm{CaO}$ & 0.009 \\
\hline $\mathrm{MgO}$ & 0.005 \\
\hline $\mathrm{Fe}_{2} \mathrm{O}_{3}$ & 0.108 \\
\hline $\mathrm{Al}_{2} \mathrm{O}_{2}$ & 0.068 \\
\hline $\mathrm{ZrO}$ & 0.016 \\
\hline $\mathrm{P}, \mathrm{O}_{2}$ & 0.004 \\
\hline Others & 0.040 \\
\hline
\end{tabular}

Notes:

Values based on Manuel, A. F., J. D. Galbraith, S. L. Lambert, and G.

E. Stegen, 1996, Phase I High-Level Waste Pretreatment and Feed

Staging Plan, WHC-SD-ES-370, Rev. 0, Westinghouse Hanford Company, Richland, Washington.

Glass Density $-2,640 \mathrm{~kg} / \mathrm{m}^{3}$

Table 3-2. Radionuclide Composition of Glass. ( 3 sheets)

\begin{tabular}{|l|l|l|l|}
\hline Isotope & $\mathrm{Ci} / \mathrm{g}$ & DCF (rem/Ci) & $\begin{array}{l}\text { Rem/g } \\
\text { respirable }\end{array}$ \\
\hline${ }^{55} \mathrm{Fe}$ & $1.6 \mathrm{E}-05$ & $2.68 \mathrm{E}+03$ & $4.29 \mathrm{E}-02$ \\
\hline${ }^{59} \mathrm{Ni}$ & $2.3 \mathrm{E}-07$ & $1.32 \mathrm{E}+03$ & $3.04 \mathrm{E}-04$ \\
\hline${ }^{60} \mathrm{Co}$ & $4.8 \mathrm{E}-05$ & $2.19 \mathrm{E}+05$ & $1.05 \mathrm{E}+01$ \\
\hline${ }^{63} \mathrm{Ni}$ & $2.6 \mathrm{E}-05$ & $3.10 \mathrm{E}+03$ & $8.06 \mathrm{E}-02$ \\
\hline${ }^{79} \mathrm{Se}$ & $6.8 \mathrm{E}-09$ & $9.84 \mathrm{E}+03$ & $6.69 \mathrm{E}-05$ \\
\hline${ }^{90} \mathrm{Sr}$ & $5.0 \mathrm{E}-02$ & $2.39 \mathrm{E}+05$ & $1.20 \mathrm{E}+04$ \\
\hline${ }^{90} \mathrm{Y}$ & $5.0 \mathrm{E}-02$ & $8.44 \mathrm{E}+03$ & $4.22 \mathrm{E}+02$ \\
\hline${ }^{93 \mathrm{~m}} \mathrm{Nb}$ & $1.4 \mathrm{E}-06$ & $2.92 \mathrm{E}+04$ & $4.09 \mathrm{E}-02$ \\
\hline${ }^{93} \mathrm{Zr}$ & $2.3 \mathrm{E}-06$ & $3.21 \mathrm{E}+05$ & $7.38 \mathrm{E}-01$ \\
\hline${ }^{99} \mathrm{Tc}$ & $7.3 \mathrm{E}-05$ & $1.02 \mathrm{E}+03$ & $7.45 \mathrm{E}-02$ \\
\hline${ }^{106} \mathrm{Ru}$ & $3.2 \mathrm{E}-06$ & $4.77 \mathrm{E}+05$ & $1.53 \mathrm{E}+00$ \\
\hline${ }^{106} \mathrm{Rh}$ & $3.2 \mathrm{E}-06$ & $2.13 \mathrm{E}+02$ & $6.82 \mathrm{E}-04$ \\
\hline${ }^{107} \mathrm{Pd}$ & $6.5 \mathrm{E}-08$ & $1.28 \mathrm{E}+04$ & $8.32 \mathrm{E}-04$ \\
\hline
\end{tabular}


Table 3-2. Radionuclide Composition of Glass. (3 sheets)

\begin{tabular}{|c|c|c|c|}
\hline Isotope & $\mathrm{Ci} / \mathrm{g}$ & $D C F($ rem/Ci) & $\begin{array}{l}\mathrm{Rem} / \mathrm{g} \\
\text { respirable }\end{array}$ \\
\hline $110 \mathrm{~m} / \mathrm{Ag}$ & $1.6 \mathrm{E}-10$ & $2.83 E+05$ & $4.53 \mathrm{E}-05$ \\
\hline${ }^{113 \mathrm{~m}} \mathrm{Cd}$ & $1.8 \mathrm{E}-05$ & $1.53 \mathrm{E}+06$ & $2.75 \mathrm{E}+0 \mathrm{I}$ \\
\hline T13m In & $3.0 \mathrm{E}-08$ & $4.11 E+01$ & $1.23 \mathrm{E}-06$ \\
\hline${ }^{113} \mathrm{Sn}$ & $3.0 \mathrm{E}-08$ & $1.07 \mathrm{E}+04$ & $3.21 \mathrm{E}-04$ \\
\hline${ }^{115 \pi} \mathrm{Cd}$ & $1.1 \mathrm{E}-11$ & $7.21 E+04$ & $7.93 \mathrm{E}-07$ \\
\hline $19 \mathrm{~m}_{\mathrm{Sn}}$ & $1.6 \mathrm{E}-10$ & $6.25 \mathrm{E}+03$ & $1.00 \mathrm{E}-06$ \\
\hline${ }^{121 m} \mathrm{Sn}$ & $1.5 \mathrm{E}-07$ & $1.15 E+04$ & $1.73 \mathrm{E}-03$ \\
\hline${ }^{126} \mathrm{Sn}$ & $7.7 \mathrm{E}-07$ & $9.95 \mathrm{E}+04$ & $7.66 \mathrm{E}-02$ \\
\hline${ }^{124} \mathrm{Sb}$ & $4.2 \mathrm{E}-11$ & $2.52 E+04$ & $1.06 \mathrm{E}-06$ \\
\hline${ }^{126} \mathrm{Sb}$ & $7.8 \mathrm{E}-08$ & $1.17 \mathrm{E}+04$ & $9.13 \mathrm{E}-04$ \\
\hline${ }^{126 m} \mathrm{Sb}$ & $5.5 \mathrm{E}-07$ & $3.39 \mathrm{E}+01$ & $1.86 \mathrm{E}-05$ \\
\hline${ }^{125} \mathrm{Sb}$ & $1.6 \mathrm{E}-04$ & $1.22 E+04$ & $1.95 \mathrm{E}+00$ \\
\hline${ }^{125 \mathrm{~m}} \mathrm{Te}$ & $4.8 \mathrm{E}-05$ & $7.29 \mathrm{E}+03$ & $3.50 \mathrm{E}-01$ \\
\hline${ }^{729} \mathrm{I}$ & $1.5 \mathrm{E}-09$ & $1.74 \mathrm{E}+05$ & $2.61 \mathrm{E}-04$ \\
\hline${ }^{134} \mathrm{Cs}$ & $1.1 \mathrm{E}-04$ & $4.63 \mathrm{E}+04$ & $5.09 \mathrm{E}+00$ \\
\hline${ }^{135} \mathrm{Cs}$ & $4.8 \mathrm{E}-07$ & $4.55 \mathrm{E}+03$ & $2.18 \mathrm{E}-03$ \\
\hline${ }^{137} \mathrm{Cs}$ & $4.8 \mathrm{E}-02$ & $3.19 E+04$ & $1.53 E+03$ \\
\hline${ }^{137 \mathrm{~m}} \mathrm{Ba}$ & $4.8 \mathrm{E}-02$ & $--^{1}$ & --1 \\
\hline${ }^{144} \mathrm{Ce}$ & $1.6 \mathrm{E}-06$ & $3.74 E+05$ & $5.98 \mathrm{E}-01$ \\
\hline${ }^{144} \mathrm{Pr}$ & $1.6 \mathrm{E}-06$ & $4.33 E+01$ & $6.93 \mathrm{E}-05$ \\
\hline${ }^{144 \mathrm{~m}} \mathrm{Pr}$ & $1.6 \mathrm{E}-09$ & $--^{2}$ & \\
\hline${ }^{147} \mathrm{Pm}$ & $2.6 \mathrm{E}-03$ & $3.92 E+04$ & $1.02 E+02$ \\
\hline${ }^{151} \mathrm{Sm}$ & $1.5 \mathrm{E}-03$ & $3.00 \mathrm{E}+04$ & $4.50 E+01$ \\
\hline${ }^{152} \mathrm{Eu}$ & $2.4 \mathrm{E}-06$ & $2.21 E+05$ & $5.30 \mathrm{E}-01$ \\
\hline${ }^{154} \mathrm{Eu}$ & $2.6 \mathrm{E}-04$ & $2.86 \mathrm{E}+05$ & $7.44 \mathrm{E}+01$ \\
\hline${ }^{155} \mathrm{Eu}$ & $1.5 \mathrm{E}-04$ & $4.14 E+04$ & $6.21 \mathrm{E}+00$ \\
\hline${ }^{234} \mathrm{U}$ & $1.2 \mathrm{E}-08$ & $1.32 \mathrm{E}+08$ & $1.58 \mathrm{E}+00$ \\
\hline${ }^{235} \mathrm{U}$ & $5.2 \mathrm{E}-10$ & $1.23 \mathrm{E}+08$ & $6.40 \mathrm{E}-02$ \\
\hline${ }^{236} \mathrm{U}$ & $1.3 \mathrm{E}-09$ & $1.25 E+08$ & $1.63 \mathrm{E}-01$ \\
\hline${ }^{238} \mathrm{U}$ & $9.4 \mathrm{E}-09$ & $1.18 \mathrm{E}+08$ & $1.11 \mathrm{E}+00$ \\
\hline${ }^{237} \mathrm{~Np}$ & $3.7 E-07$ & $5.40 E+08$ & $2.00 \mathrm{E}+02$ \\
\hline${ }^{238} \mathrm{Pu}$ & $1.8 \mathrm{E}-06$ & $2.88 E+08$ & $5.18 \mathrm{E}+02$ \\
\hline${ }^{239} \mathrm{Pu}$ & $1.5 \mathrm{E}-05$ & $3.08 \mathrm{E}+08$ & $4.62 E+03$ \\
\hline${ }^{240} \mathrm{Pu}$ & $4.2 \mathrm{E}-06$ & $3.08 \mathrm{E}+08$ & $1.29 \mathrm{E}+03$ \\
\hline${ }^{241} \mathrm{Pu}$ & $1.1 \mathrm{E}-04$ & $4.96 \mathrm{E}+06$ & $5.46 \mathrm{E}+02$ \\
\hline${ }^{242} \mathrm{Pu}$ & $1.1 \mathrm{E}-09$ & $2.93 \mathrm{E}+08$ & $3.22 \mathrm{E}-01$ \\
\hline${ }^{241} \mathrm{Am}$ & $6.9 \mathrm{E}-04$ & $4.44 E+08$ & $3.06 \mathrm{E}+05$ \\
\hline${ }^{242} \mathrm{Am}$ & $5.0 \mathrm{E}-07$ & $5.85 \mathrm{E}+04$ & $2.93 \mathrm{E}-02$ \\
\hline${ }^{24 \mathrm{~m}} \mathrm{Am}$ & $5.2 E-07$ & $4.26 \mathrm{E}+08$ & $2.22 E+02$ \\
\hline
\end{tabular}


Table 3-2. Radionuclide Composition of Glass. (3 sheets)

\begin{tabular}{|l|l|l|l|}
\hline Isotope & $\mathrm{Ci} / \mathrm{g}$ & DCF (rem/Ci) & $\begin{array}{l}\text { Rem } / \mathrm{g} \\
\text { respirable }\end{array}$ \\
\hline${ }^{243} \mathrm{Am}$ & $8.1 \mathrm{E}-08$ & $4.40 \mathrm{E}+08$ & $3.56 \mathrm{E}+01$ \\
\hline${ }^{242} \mathrm{Cm}$ & $6.0 \mathrm{E}-07$ & $1.73 \mathrm{E}+07$ & $1.04 \mathrm{E}+01$ \\
\hline${ }^{244} \mathrm{Cm}$ & $1.5 \mathrm{E}-05$ & $2.48 \mathrm{E}+08$ & $3.72 \mathrm{E}+03$ \\
\hline \multicolumn{2}{c}{$\begin{array}{l}\text { Included in } \\
\text { 2 }\end{array}$ None provided in EPA (1988) } & Total & $3.30 \mathrm{E}+05$ \\
\cline { 2 - 4 } & &
\end{tabular}

Table 3-3. Cessium-Loaded Ion Exchange Resin Properties.

\begin{tabular}{|c|c|}
\hline oxide & kg Oxide/kg Zeolite \\
\hline $\mathrm{SiO}_{2}$ & 0.14 \\
\hline $\mathrm{Na}_{2} \mathrm{O}$ & 0.16 \\
\hline $\mathrm{IiO}_{2}$ & 0.36 \\
\hline $\mathrm{H}_{2} \mathrm{O}$ & 0.10 \\
\hline Others & 0.24 \\
\hline
\end{tabular}

Table 3-4. Radionuclide Compositions in Undiluted Supernate IX Column Feed.*

\begin{tabular}{|c|c|c|c|}
\hline Radionuclide & $\mathrm{Ci} / \mathrm{gal}$ & DCF rem/Ci & rens/gallon \\
\hline${ }^{3} \mathrm{H}$ & 2.23E-05 & $6.40 E+01$ & $1.43 \mathrm{E}-03$ \\
\hline${ }^{14} \mathrm{C}$ & $1.40 \mathrm{E}-06$ & $2.10 \mathrm{E}+03$ & $2.94 \mathrm{E} * 03$ \\
\hline${ }^{60} \mathrm{Co}$ & $7.34 \mathrm{E}-05$ & $2.19 E+05$ & $1.61 E+01$ \\
\hline${ }^{79} \mathrm{Se}$ & $1.82 E-06$ & $9.84 \mathrm{E}+03$ & $1.79 E-02$ \\
\hline${ }^{90} \mathrm{Sr}$ & $3.82 E-03$ & $2.39 E+05$ & $9.13 E+02$ \\
\hline${ }^{90} \mathrm{Y}$ & $3.82 E-03$ & $8.44 E+03$ & $3.22 E+01$ \\
\hline${ }^{93 \mathrm{~m}} \mathrm{Nb}$ & $2,58 \mathrm{E}-04$ & $2.92 E+04$ & $7.53 \mathrm{E}-00$ \\
\hline${ }^{99} \mathrm{TC}$ & $5.75 E-04$ & $1.02 E+03$ & $5.87 \mathrm{E}-01$ \\
\hline${ }^{106} \mathrm{Ru}$ & $1.58 \mathrm{E}-03$ & $4.77 E+05$ & $7.54 E+02$ \\
\hline${ }^{129} \mathrm{I}$ & 1.15E-06 & $1.74 \mathrm{E}+05$ & $2.00 \mathrm{E}-01$ \\
\hline${ }^{134} \mathrm{Cs}$ & $1.97 \varepsilon-03$ & 4. $63 E+04$ & $9.12 E+01$ \\
\hline${ }^{137} \mathrm{Cs}$ & $1.83 \mathrm{E}-00$ & $3.19 E+04$ & $5.84 \mathrm{E}+04$ \\
\hline${ }^{237} \mathrm{~Np}$ & $8.18 E-07$ & $5.4 E+08$ & $4.42 E+02$ \\
\hline${ }^{239} \mathrm{Pu} /{ }^{240} \mathrm{Pu}$ & $4.31 E-06$ & $3.08 \mathrm{E}+08$ & $1.33 \mathrm{E}+03$ \\
\hline${ }^{241} \mathrm{Am}$ & $4.54 \mathrm{E}-06$ & $4.44 E+08$ & $2.02 E+03$ \\
\hline${ }^{243} \mathrm{Cm}$ & $1.87 \mathrm{E}-07$ & $3.07 E+08$ & $5.74 E+01$ \\
\hline
\end{tabular}

*This source term is used only for the abnormal event that liquid is retained in the ion exchange resin. 
WHC-SD-WM-TI-781, Rev. 0

\subsection{RADIONUCLIDE INVENTORIES}

The following describes the radionuclide inventories of the solidified HLW glass canisters and cesium ion exchange resin containers (cesium containers).

\subsubsection{Glass Canisters}

There are two sizes of glass canisters, one containing $1,650 \mathrm{~kg}$ of glass and the other with a capacity of $2,735 \mathrm{~kg}$ of $\mathrm{glass}$. The glass canisters are stainless steel with a welded leak-tight closure. The density of the glass is $2,640 \mathrm{~kg} / \mathrm{m}^{3}$. The radionuclide composition of the $\mathrm{glass}$ in curie/gram $(\mathrm{Ci} / \mathrm{g})$ is shown in Table 3-2. Also shown are the dose conversion factors (EPA 1988) for each of the isotopes, while the final column of Table 3-2 shows the

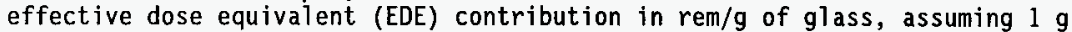
of glass as respirable ( $\leq 10$ micron). The $\mathrm{Pu}$ isotopes are all assumed to be in the oxide form. The total for all isotopes' DCFs is $3.30 \times 10^{5}$ rem per $\mathrm{g}$ of glass released as respirable. Additional pertinent information on the two glass canisters are as follows:

- Standard Canister

Nominal length $-3.0 \mathrm{~m}$

Nominal diameter $-60.96 \mathrm{~cm}$

Wall thickness - $0.95 \mathrm{~cm}$

Material of construction - 304L stainless steel

Canister weight (empty) - $454 \mathrm{~kg}$

G1ass content - $1,650 \mathrm{~kg}$

Total canister weight $(\mathrm{full})-2,100 \mathrm{~kg}$

Internal volume $-0.74 \mathrm{~m}^{3}$

Maximum allowable centerline temperature $-400{ }^{\circ} \mathrm{C}$

- Large Canister

Nominal length $-4.5 \mathrm{~m}$

Nominal diameter - $60.96 \mathrm{~cm}$

Wall thickness $-0.95 \mathrm{~cm}$

Material of construction - 304L stainless steel

Canister weight (empty) - $667 \mathrm{~kg}$

Glass content - 2,735 kg

Total canister weight ( $f(u) 11)-3,402 \mathrm{~kg}$

Internal Volume - $1.15 \mathrm{~m}^{3}$

Maximum allowable centerline temperature $-400{ }^{\circ} \mathrm{C}$

\subsubsection{Cesium Ion Exchange Resin Containers (Cesium Containers)}

The cesium containers will contain inorganic ion exchange resin and can have up to $3.2 \times 10^{5} \mathrm{Ci}$ of ${ }^{137} \mathrm{Cs} /{ }^{137 \mathrm{~m}} \mathrm{Ba}$ in each container. However, the 
aggregate per storage tube inventory will not exceed $3.2 \times 10^{5} \mathrm{Ci}$ of ${ }^{137} \mathrm{Cs} /{ }^{137 \mathrm{~m}} \mathrm{Ba}$ and $2.1 \mathrm{Ci}$ of ${ }^{135} \mathrm{Cs}$ regardless of the number of containers per storage tube. The cesium containers will be stainless steel with a welded leak-tight closure. The bulk density of the resin is $1,000 \mathrm{~kg} / \mathrm{m}^{3}$. The chemical composition of the material as received from the vendor is shown in Table 3-3. The ion exchange media as received from the vendor has a particle size of 30 to 60 mesh $(595$ to $250 \mu \mathrm{m})$. Because no information is provided on the percentage of fines in the resin, it is assumed for accident analysis purposes that $0.1 \%$ of the resin will have been reduced to particles with a diameter of $<10 \mu \mathrm{m}$. The ion exchange resin contains ten weight percent water as received from the vendor. Although the product specifications require that the stored product be dried, it is assumed that a volume of ion exchange feed equal to the volume of water from the vendor could be retained in the cesium container for one of the accident scenarios. The radionuclide concentration of the undiluted supernate used in Cesium Demonstration Unit Preliminary Safety Evaluation (Ebasco/BNFL, 1994) is assumed (Table 3-4). Additional pertinent information for the cesium containers is as follows:

- Cesium Container

$$
\begin{aligned}
& \text { Maximum length }-1.37 \mathrm{~m} \\
& \text { Maximum diameter }-33 \mathrm{~cm} \\
& \text { Wall thickness }-0.95 \mathrm{~cm} \\
& \text { Material of construction - } 304 \mathrm{~L} \text { stainless steel } \\
& \text { Container weight (empty) - } 212 \mathrm{~kg} \\
& \text { Cesium-loaded ion exchange resin weight }-84 \mathrm{~kg} \\
& \text { Total weight - } 296 \mathrm{~kg}
\end{aligned}
$$

\subsection{ACCIDENT ANALYSIS}

The accident analysis was conducted to evaluate the hazards, develop accident scenarios, and define systems, structures, and components (SSCS) important to safety for the transfers and storage of HLW in the CSB facility.

\subsection{CSB STORAGE HAZARDS}

This evaluation identified the abnormal occurrences during CSB storage to determine the hazardous events for the accident analysis.

\subsubsection{Abnormal Occurrences During CSB Storage}

The postulated abnormal occurrences that could cause the confinement of radionuclides to be breached are 1 isted in Table 4-1. 
Table 4-1. Postulated Abnormal Occurrences During CSB Receiving and Storage (2 Sheets).

\begin{tabular}{|c|c|c|}
\hline OCCURRENCE & CAUSE & SAFEGUARDS \\
\hline External phenomena & $\begin{array}{l}\text { Seismic event } \\
\text { Lightning } \\
\text { Airplane crash }\end{array}$ & Emergency procedures \\
\hline $\begin{array}{l}\text { Damage to canister or container } \\
\text { because of dropping heavy object } \\
\text { (shield ring or cask lid) on } \\
\text { canister or container during } \\
\text { receiving }\end{array}$ & $\begin{array}{l}\text { Human error } \\
\text { Hoist failure }\end{array}$ & Training and procedures \\
\hline $\begin{array}{l}\text { Damage to cesium container because } \\
\text { of hydrogen explosion }\end{array}$ & $\begin{array}{l}\text { Hydrogen buildup in cesium } \\
\text { container from incomplete drying } \\
\text { causing radiolysis and ignition } \\
\text { source }\end{array}$ & Controls to assure complete drying \\
\hline Hydrogen explosion in storage tube & $\begin{array}{l}\text { Hydrogen bui ldup in cesiun } \\
\text { container, leakage of hydrogen } \\
\text { from the container and spark } \\
\text { source } \\
\text { or } \\
\text { External leakage of water into } \\
\text { storage tube, radiolys is of the } \\
\text { water, and spark source }\end{array}$ & $\begin{array}{l}\text { Design of container, } \\
\text { adninistrative controls on water } \\
\text { removal } \\
\text { Design of storage tubes; } \\
\text { surveillance }\end{array}$ \\
\hline Hydrogen explosion in MHM & $\begin{array}{l}\text { Hydrogen buil ldup in cesium } \\
\text { cantainer, leakage of hydrogen } \\
\text { from the container and spark } \\
\text { source }\end{array}$ & $\begin{array}{l}\text { Adninistrative controls on water } \\
\text { removal }\end{array}$ \\
\hline $\begin{array}{l}\text { Damage to glass canister or cesium } \\
\text { container during receiving } \\
\text { sequence }\end{array}$ & Human error & $\begin{array}{l}\text { Training and procedures } \\
\text { Maintenance and inspection of } \\
\text { components }\end{array}$ \\
\hline Truck accident in receiving bay & $\begin{array}{l}\text { Human error } \\
\text { Truck mechanical failure }\end{array}$ & $\begin{array}{l}\text { Training and procedures--driver } \\
\text { qual if ication } \\
\text { Maintenance and inspection of } \\
\text { truck components }\end{array}$ \\
\hline Truck fire in receiving bay & Same as above & Sane as above \\
\hline $\begin{array}{l}\text { Dropping cask/canister or cesium } \\
\text { container into receiving area when } \\
\text { lifting cask from transport } \\
\text { trailer }\end{array}$ & $\begin{array}{l}\text { Human error } \\
\text { Receiving crane failure } \\
\text { Failure of lifting yoke }\end{array}$ & $\begin{array}{l}\text { Training and procedures } \\
\text { Maintenance and inspection of } \\
\text { lifting components }\end{array}$ \\
\hline $\begin{array}{l}\text { Overpressurization of the cesium } \\
\text { container during receiving }\end{array}$ & $\begin{array}{l}\text { Buildup of hydrogen because of } \\
\text { inadequate water removal } \\
\text { Buildup of steam because of } \\
\text { insdequate water removal and } \\
\text { overheating during transport }\end{array}$ & Controls to assure complete drying \\
\hline $\begin{array}{l}\text { MHM travels w/o locking pins } \\
\text { engaged causing glass canister or } \\
\text { cesium container to drop if } \\
\text { seismic event occurs }\end{array}$ & $\begin{array}{l}\text { Human error } \\
\text { Failure of control system }\end{array}$ & $\begin{array}{l}\text { Control system inhibits travel } \\
\text { unless locking pins are engaged }\end{array}$ \\
\hline
\end{tabular}


WHC-SD-WM-TI-781, Rev. 0

Table 4-1. Postulated Abnormal 0ccurrences During CSB Receiving and Storage (2 Sheets).

\begin{tabular}{|c|c|c|}
\hline OCCURRENCE & CAUSE & SAFEGUARDS \\
\hline $\begin{array}{l}\text { Drop glass canister or cesium } \\
\text { container because of damaged hoist }\end{array}$ & $\begin{array}{l}\text { Overraising the hoist while } \\
\text { carrying the gloss canister or } \\
\text { cesium container }\end{array}$ & Limit switches \\
\hline $\begin{array}{l}\text { Damage to glass canister or cesium } \\
\text { container because of hoist } \\
\text { snagging }\end{array}$ & $\begin{array}{l}\text { Overlowering the canister hoist } \\
\text { while carrying the container }\end{array}$ & Limit switches and resolver \\
\hline $\begin{array}{l}\text { Dropping glass canister or cesium } \\
\text { container in transit to storage } \\
\text { location }\end{array}$ & $\begin{array}{l}\text { Grapple prematurely disengaged or } \\
\text { engaged when load is improperly } \\
\text { positioned }\end{array}$ & $\begin{array}{l}\text { Limit switches } \\
\text { Weight sensing system } \\
\text { Control system }\end{array}$ \\
\hline $\begin{array}{l}\text { Damage to glass canister or cesium } \\
\text { container during lowering into } \\
\text { storage tube }\end{array}$ & $\begin{array}{l}\text { Lateral movement of MHM while } \\
\text { container is being lowered or } \\
\text { stuck part way because of too many } \\
\text { impact absorbers, wrong vault, or } \\
\text { poor clearance. }\end{array}$ & Mechanical interlock on MHM \\
\hline $\begin{array}{l}\text { Damage to glass canister or cesium } \\
\text { container during raising from } \\
\text { storage tube }\end{array}$ & Same as above & Same as above \\
\hline $\begin{array}{l}\text { Glass canister or cesium container } \\
\text { dropped into service pit onto } \\
\text { newly received glass canister or } \\
\text { cesium container prepared for } \\
\text { storage }\end{array}$ & $\begin{array}{l}\text { Misrouting of an MHM already } \\
\text { containing a cesium container or } \\
\text { glass canister to service station }\end{array}$ & $\begin{array}{l}\text { Administrative control and } \\
\text { accountability } \\
\text { Weight indication on mhm grapple }\end{array}$ \\
\hline $\begin{array}{l}\text { Melting of glass canister or } \\
\text { cesium container because of } \\
\text { overheating in storage tube }\end{array}$ & $\begin{array}{l}\text { Decay heat and loss of storage } \\
\text { tube cooling system }\end{array}$ & Emergency procedures \\
\hline $\begin{array}{l}\text { Over-pressurization of the cesium } \\
\text { container during storage }\end{array}$ & $\begin{array}{l}\text { Hydrogen accumulation because of } \\
\text { failure to completely dry ion } \\
\text { exchange resin } \\
\text { steam pressurization because of } \\
\text { heating of cesium container } \\
\text { because of decay heat and loss of } \\
\text { cooling }\end{array}$ & $\begin{array}{l}\text { Controls to assure complete drying } \\
\text { of ion exchange resin }\end{array}$ \\
\hline $\begin{array}{l}\text { Corrosion of glass canister or } \\
\text { cesium container }\end{array}$ & $\begin{array}{l}\text { Materials incompatibility of waste } \\
\text { with container (excess chlorides, } \\
\text { e. G.) } \\
\text { Contamination of welds }\end{array}$ & $\begin{array}{l}\text { Quality control; design of } \\
\text { containers }\end{array}$ \\
\hline $\begin{array}{l}\text { Damage to two containers during } \\
\text { storage tube loading }\end{array}$ & $\begin{array}{l}\text { Drop of top container on top of } \\
\text { second container }\end{array}$ & $\begin{array}{l}\text { Impact absorbers at bottom of } \\
\text { storage tube and between } \\
\text { containers }\end{array}$ \\
\hline $\begin{array}{l}\text { Damage to lower container because } \\
\text { of placing second unlike container } \\
\text { on top of lower container }\end{array}$ & Human error in container placement & $\begin{array}{l}\text { Cesium container designed to bear } \\
\text { full weight of glass canister and } \\
\text { impact absorber (not yet } \\
\text { specified) }\end{array}$ \\
\hline $\begin{array}{l}\text { Melting of contents of glass } \\
\text { canister or cesium container } \\
\text { because of overheating in MHM }\end{array}$ & $\begin{array}{l}\text { Decay heat and loss of MHM cooling } \\
\text { systen and loss of ability to move } \\
\text { mhm to location where container } \\
\text { can be removed }\end{array}$ & $\begin{array}{l}\text { Emergency procedures } \\
\text { Backup power to MHM ventilation } \\
\text { system }\end{array}$ \\
\hline
\end{tabular}




\subsubsection{RESULTS/DISCUSSION OF CSB STORAGE}

The CSB storage activities, as evaluated in this report, include a number of uncertainties. One activity that was not evaluated was replacement of the MHM internal transport cask. Depending upon where the upgrade work is performed, safety-class structures could be at risk. This activity will be included in the evaluation performed during conceptual design. In addition to Preliminary Hazard Analysis, which have been performed for the CSB and the safety analyses for the HWVP, a number of draft operating manuals were reviewed, and a number of assumptions made about the applicability of the process description to the glass canisters and cesium containers. Assumptions are as follows:

- Glass canister sizes will be those shown in Section 3.1.1

- Cesium container sizes are those shown in Section 3.1.2

- The radionuclide content of the glass is as shown in Table 3-2

- The maximum radionuclide content of a single cesium container or single storage well holding up to six containers is $3.2 \times 10^{5} \mathrm{Ci}{ }^{137} \mathrm{Cs}$

- The maximum normal fines fraction (based on fracturing during cooling) of glass is the same as that used in the HWVP Preliminary Safety Analys is Report (PSAR) (see Section 4.2.3.1, Source Term Analysis)

- The cesium resin used will be inorganic

- Cesium ion exchange resin will be dried so that there are no free liquids and insufficient remaining water to generate sufficient hydrogen to overpressure the container or create an explosion hazard

- The drying and handling process for cesium ion exchange resin will not create greater than 0.1 wt\% "fine" (less than 10 micron) particles

- Containers (cesium containers and glass canisters) are not vented

- Storage tube depth is $12.8 \mathrm{~m}$ (per the HWVP PSAR; the SNF Preliminary Safety Evaluation assumed a storage tube depth of slightly over $13 \mathrm{~m}$ )

- Criteria for safety-class and safety-significant equipment remain as stated in WHC-CM-4-46

- The use of impact absorbers at the bottom of the storage tubes and in between containers is assumed, although no further credit is taken in the unmitigated analysis

- It is assumed that the MHM grapple will be designed to not allow release of the grapple with a load. 
A scenario that may not have been examined is the possibility of misrouting a full MHM to pick up a full container (glass canister or cesium container) that has just arrived at the CSB. The MHM grapple does have weight indication, but that seems to be the only hardware method of ascertaining whether the MHM has a payload. An initial step in the process of picking up a container is releasing the grapple so that it can be used to grasp the newlyarrived container. If the weight indication did not show that the MHM had a payload, it might be dropped onto the newly-arrived container. Confinement would probably be maintained, but recovery actions might be extensive.

Yet another scenario that was postulated in previous hazards analysis was dropping a container onto another container already in a storage tube. The hazard analysis assumption was that each tube would contain two impact absorbers to prevent the containers from being damaged by a drop accident, one to prevent the bottom container from being damaged if dropped, the other to prevent the top container and bottom container from being damaged if the top one was dropped on the bottom one. This analysis does not take credit for the impact absorbers for safety class determination.

Dropping a full cask/container is an undesirable occurrence. It was noted in the operating manuals that the receiving crane is radio controlled. If random radio signals could lead to a condition that might result in dropping the cask and/or the container, it should be assured that the crane signal is unique.

It is assumed for the purposes of this report that it might be possible to mix containers (a glass canister and a cesium container) in the storage tube. It is further assumed that this event would not be planned but might be possible if both kinds of containers were being placed into storage during the same time period. A safety feature to prevent undesirable consequences (damage to a cesium container) would be designing the external frame for the cesium container to bear the weight of an impact absorber and a glass canister. It is assumed in the abnormal occurrence table that this safety feature will be implemented.

It is unknown whether or not the storage tubes will be periodically monitored as the storage tubes for spent fuel are planned to be. It is assumed in this report that periodic monitoring of the storage tubes for release of radioactive material from a container will be performed. Because it is assumed that the ion exchange resin will be dried before the column is sealed, it is assumed that the storage tubes will not be inerted, nor will they be monitored for hydrogen.

\subsubsection{Accidents for Further Analysis}

Five types of abnormal events other than external events are deemed credible that might cause damage to the containers (glass canisters or cesium containers). The types of abnormal events are:

- Container corrosion 
- $\quad$ verheating (because of loss of cooling in either the MHM or the storage tube)

- Drop accidents of various types

- Pressurization (caused by steam from the residual water overheating, hydrogen evolution, or hydrogen burn) of the cesium containers because of failure to completely dry the ion exchange resin

- Catastrophic failure of the container because of shearing during handling or external pressure from hydrogen detonation in the storage tube.

These accidents were further grouped into bounding scenarios for mechanical damage and internal pressurization for each of the container types.

\subsection{CONSEQUENCES OF ACCIDENTS}

\subsubsection{Consequence Analys is}

Radiological inhalation dose consequences for each accident analyzed are based on the following.

- Mass of material available for release

- Airborne release fraction (ARF) and (RF)

- Dose conversion factors

- Atmospheric dispersion of airborne particles

- Duration of exposure

- Breathing rates.

The radiological dose to a maximum receptor of interest is typically determined by using the following equation.

$$
D=M \times \frac{X}{Q} \times R \times C
$$

where

$$
\begin{aligned}
D & =\text { Dose (rem) } \\
M & =\text { Mass of material released }(\mathrm{g}) \\
x / Q & =\text { Time-integrated atmospheric dispersion coefficient }\left(\mathrm{s} / \mathrm{m}^{3}\right) \\
R & =\text { Breathing rate }\left(\mathrm{m}^{3} / \mathrm{s}\right) \\
C & =\text { Dose per unit respirable radioactive material inhaled }(\mathrm{rem} / \mathrm{g})
\end{aligned}
$$

The quantity of respirable material released $(M)$ is determined by the specific accident scenario. The atmospheric dispersion coefficient $(x / Q)$ is based on specific release conditions (e.g., ground level or elevated, long or short duration) and the receptor's distance from the release. The atmospheric dispersion coefficient is the time-integrated normalized air concentration at the receptor's location. The coefficient represents the dilution of an 
airborne contaminant caused by atmospheric mixing and turbulence. All $x / Q$ values for these analyses have been generated using the $G \times Q$ computer program (Hey 1993a and Hey 1993b). Table 4-2 contains the $X / Q$ values used to determine onsite and offsite consequences.

Values of $X / Q$ were calculated for various distances from the release in the full range of compass directions. For these analyses, the worst-case meteorology (windspeed and direction) for the Hanford Site was used to determine the location at the Site boundary where the maximum doses would occur. The same approach was used to determine the direction of the maximum doses at $100 \mathrm{~m}(328 \mathrm{ft})$.

Table 4-2. Atmospheric Dispersion Coefficients Used in Accident Analyses for the CSB.

\begin{tabular}{|c|c|c|c|}
\hline \multirow[b]{2}{*}{ Receptor Location Description } & \multicolumn{3}{|c|}{$\begin{array}{c}X / 0 \\
\text { Point Source }\left(s / m^{3}\right)\end{array}$} \\
\hline & $\begin{array}{l}\text { Wi thout plume } \\
\text { meander, wi thout } \\
\text { stack }\end{array}$ & $\begin{array}{l}\text { With plume } \\
\text { meander, without } \\
\text { stack }\end{array}$ & $\begin{array}{l}\text { Stack release (one } \\
\text { fan at } 5.66 \mathrm{~m}^{3} / \mathrm{s} \text { ) }\end{array}$ \\
\hline $\begin{array}{l}\text { Onsite } \\
(100 \mathrm{mE})\end{array}$ & $3.41 \mathrm{E}-02$ & $1.13 \mathrm{E}-02$ & $\begin{array}{l}4.18 \mathrm{E}-05 \\
(230 \mathrm{~m} \mathrm{~W})\end{array}$ \\
\hline $\begin{array}{l}\text { Hanford site boundary } \\
(18.3 \mathrm{~km} \mathrm{E})\end{array}$ & $1.32 \mathrm{E}-05$ & $1.11 \mathrm{E}-05$ & 7.14 E-06 \\
\hline Near river bank $(15.0 \mathrm{~km} \mathrm{E})$ & $1.96 \mathrm{E}-05$ & $1.55 E-05$ & $8.31 E-0.6$ \\
\hline
\end{tabular}

For calculation of offsite releases, values of $x / Q$ were calculated for a receptor in the highest dose direction at the Hanford Site boundary and for a maximum dose receptor at the Columbia River to the east and a proposed boundary at Highway 240 to the west. The maximum offsite receptor for the Site boundary was found to be at a location $18.3 \mathrm{~km}(11.3 \mathrm{mi})$ east of the CSB. The maximum offsite receptor at the near river boundary $15 \mathrm{~km}(9.3 \mathrm{mi})$ east of the facility was found to be more limiting than one at Highway 240 . This is the case even though Highway 240 is closer to the facility. The maximum onsite $(100 \mathrm{~m}[328 \mathrm{ft}])$ receptor was east of the facility for the ground-level release.

Correction to the $X / Q$ may be taken for building wake effects if the accident does not change the building configuration. To provide conservatism in the analysis, none of the accidents analyzed in this document used building wake effect corrections. Correction for plume meander is credited for ground releases assumed to occur during neutral or stable atmospheric conditions with windspeeds less than $6 \mathrm{~m} / \mathrm{s}(19.7 \mathrm{ft} / \mathrm{s})$ and with release times greater than 1 hour.

The breathing rate $(R)$ depends on activity factors and exposure duration. All accidents analyzed assume 8-hour exposure (the duration of a typical working shift) to the onsite receptor and 24-hour exposure to the offsite receptor. It is assumed that within one day's time, emergency 
measures will have caused evacuation of offsite areas affected by the accident. Therefore, the breathing rate used is the acute, light activity rate given in Reference Man: Anatomical, Physiological, and Metabolic characteristics (ICRP 1975). Its value is $3.3 \times 10^{-4} \mathrm{~m}^{3} / \mathrm{s}$. The dose per unit material inhaled (C) is the value for the total committed effective dose equivalent.

The major radiation exposure pathway for the identified accidents is inhalation of radioactive material. Dose contributions from the submersion pathway were not calculated and are assumed to be negligible with respect to the total dose for the radionuclides of interest. Doses from groundshine are al so expected to be negligible, therefore, the dose from groundshine and submersion are not included in the radiological dose calculations.

Potential doses from the ingestion pathway are not considered because DOE, state, and federal emergency preparedness plans 7 imit ingestion of contaminated food in the event of an accident. DOE/RL-94-02, Hanford Emergency Response Plan (DOE-RL 1995), governs emergency response for all Hanford Site facilities. The primary determinant of exposure from the ingestion pathway is the effectiveness of public health measures (i.e., interdiction) rather than the severity of the accident itself. The ingestion pathway, if it occurs, is a relatively slow-to-develop pathway and is not considered an immediate threat to an exposed population in the same sense as the inhalation pathway.

\subsubsection{Radionuclide Inventories}

The radionuclide inventories of the solidified HLW glass canisters and cesium ion exchange resin containers (cesium containers) are described in Section 3.0 .

\subsubsection{Accident Scenarios}

4.2.3.1 Multiple Glass Canister Failure during Handling-MHM Drop. Dropping a glass canister from the MHM into a tube that already contains one or more glass canisters is an operational accident caused by human error or equipment failure. Other initiating events that could potentially result in catastrophic failure of a glass canister would be shearing the container because of inadvertently closing the MHM lower shielding doors during the process of raising or lowering the canister. The accident is classified as a containment failure.

Scenario Development. A MHM failure or human error during raising or lowering operations results in dropping a glass canister into a tube that already contains one or more canisters. The storage tube is not actively ventilated, although it will be vented via a cartridge filter to the operating area. Cooling is provided by natural convection that occurs through the vault. This natural convection flow is around the exterior of the tube, and is then exhausted through the CSB stack. The MHM will be in place over the tube when the drop occurs and the MHM tube seal is designed to maintain a seal 
for the tube. The canister is designed to withstand a drop of $7 \mathrm{~m}$ onto a flat, essentially unyielding surface without breaching or dispersing radionuclides. Since a tube can hold two large canisters or three small canisters and since the material at risk is larger for two large canisters, it is assumed that one large canister is already in the tube. Each large canister is $4.5 \mathrm{~m}$ in height and with one already in the tube, the height of the drop is approximately $12.8 \mathrm{~m}-4.5 \mathrm{~m}=8.3 \mathrm{~m}$. The canister is designed to not fail catastrophically if it is dropped with an impact absorber in place at the bottom of the tube and with an impact absorber above the existing canister in the tube. For this scenario, it is assumed the impact absorbers are not in place, so the dropped canister is assumed to rupture along with the one already in the tube, releasing airborne particulate from the shattered glass within. The tube is initially not assumed to maintain its containment function so that releases from the canisters enter the vault area or the CSB area. Particles suspended in the MHM-tube confinement are assumed to enter the building through breaches/unfiltered leak paths in the system.

Source Term Analysis. The inventory at risk is the total inventory of two large canisters, or $5,470 \mathrm{~kg}$ of glass. The drop height is $9.5 \mathrm{~m}$, which exceeds the $7 \mathrm{~m}$ the canisters are designed. Farnsworth et al. (1988) performed drop tests of simulated HWV glass from a $9 \mathrm{~m}(30 \mathrm{ft})$ height. Upon disassembling the canister Farnsworth et a1. determined that 0.10 wt\% of the waste form had fractured into fines $<74 \mu \mathrm{m}$, and $0.014 \mathrm{wt} \%$ had fractured into fines $<10 \mu \mathrm{m}$. A drop of the canister from $0.3 \mathrm{~m}(1 \mathrm{ft})$, the values were $0.021 \mathrm{wt} \%$ and $0.004 \mathrm{wt} \%$ respectively. Farnsworth et al. concluded that the fines measured in the canister dropped $0.3 \mathrm{~m}(1 \mathrm{ft})$ were primarily created before impact, because of thermal stresses induced during normal cooling of the glass. Although the drop height in this case is slightly less than the 9 $m$ tests, it is assumed the ARF times the RF (ARF $x$ RF) for this scenario is $1.4 \times 10^{-4}$. With $5,470 \mathrm{~kg}$ of glass for the two large canisters and with the canisters breaching, $5.47 \times 10^{-6} \mathrm{~g} \times 1.4 \times 10^{-4}=766 \mathrm{~g}$ are released as respirable within the tube. No credit is taken for any source term reduction because of agglomeration, gravitational settling, and plateout on the surfaces.

Unmitigated Consequence Analysis. The released source term is used to determine the radiological doses to the onsite and offsite receptors. The following assumptions are used to determine the radiological consequences to human receptors.

- Only short-term exposure effects resulting from inhalation are evaluated.

- The values of $\chi / Q$ for the selected receptor locations are those given in Table 4-2 for releases without plume meander.

- The dose per unit of respirable radioactive material inhaled is the total given in Table $3-2\left(3.3 \times 10^{5} \mathrm{rem} / \mathrm{g}\right)$.

Using the relationship of:

The unmitigated onsite dose is calculated as: 
WHC-SD-WM-TI-781, Rev. 0

$$
D=M \times \frac{X}{Q} \times R \times C
$$

Dose $_{\text {onsite }}=(766 \mathrm{~g})\left(3.41 \times 10^{-2} \mathrm{~s} / \mathrm{m}^{3}\right)\left(3.3 \times 10^{-4} \mathrm{~m}^{3} / \mathrm{s}\right)\left(3.3 \times 10^{5} \mathrm{rem} / \mathrm{g}\right)=$

$$
2,845 \text { rem }
$$

The unmitigated doses are summarized in Table 4-3.

Table 4-3. Unmitigated Dose Consequences for a Dropped Glass Canister Onto Another Canister.

\begin{tabular}{|c|c|c|c|}
\hline \multirow{2}{*}{ Receptor Location } & \multicolumn{2}{|c|}{$\begin{array}{c}\text { Point Source Without Stack or } \\
\text { Plume Meander }\end{array}$} & \multirow{2}{*}{$\begin{array}{c}\text { Guidel ine } \\
\text { mSv (rem) }\end{array}$} \\
\cline { 2 - 4 } & $\begin{array}{c}x / Q \\
\left(\mathrm{~s} / \mathrm{m}^{3}\right)\end{array}$ & $\begin{array}{c}\mathrm{EDE} \\
\mathrm{mSv} \text { (rem) }\end{array}$ & \\
\hline $\begin{array}{c}\text { Onsite } \\
(100 \mathrm{~m} \mathrm{E})\end{array}$ & $3.41 \mathrm{E}-02$ & $\begin{array}{c}2.8 \mathrm{E}+04 \\
(2.8 \mathrm{E}+03 \mathrm{rem})\end{array}$ & $\begin{array}{c}5.0 \mathrm{E}+01 \\
(5.0 \mathrm{E}+00 \mathrm{rem})\end{array}$ \\
\hline $\begin{array}{c}\text { Hanford Site boundary } \\
(18.3 \mathrm{~km} \mathrm{E})\end{array}$ & $1.32 \mathrm{E}-05$ & $\begin{array}{c}1.1 \mathrm{E}+01 \\
(1.1 \mathrm{E}+00 \mathrm{rem})\end{array}$ & $\begin{array}{c}5.0 \mathrm{E}+00 \\
(5.0 \mathrm{E}-01 \mathrm{rem})\end{array}$ \\
\hline $\begin{array}{c}\text { Near river bank } \\
(15.0 \mathrm{~km} \mathrm{E})\end{array}$ & $1.96 \mathrm{E}-05$ & $\begin{array}{c}1.6 \mathrm{E}+01 \\
(1.6 \mathrm{E}+00 \mathrm{rem})\end{array}$ & $\begin{array}{c}5.0 \mathrm{E}+00 \\
(5.0 \mathrm{E}-01 \mathrm{rem})\end{array}$ \\
\hline
\end{tabular}

Note: Guidelines are from WHC-CM-4-46, Monreactor Facility Safety Analysis Manual, West inghouse Hanford Company.

EDE = effective dose equivalent.

Mitigated Consequence Analysis. With the tube remaining intact and the MHM tube seal in place at the top of the tube, only a small amount of leakage is possible. The interior volume of an empty tube is $4.73 \mathrm{~m}^{3}$ and the internal volume of the MHM cavity is $1,50 \mathrm{~m}^{3}$. The glass in each large glass canister occupies approximately $1.15 \mathrm{~m}^{3}$. The volume occupied by each of the large ruptured canisters is approximately $0.12 \mathrm{~m}^{3}$. Therefore, the total void volume within the tube assuming no impact limiters in $\mathrm{place}$ is approximately $4.73 \mathrm{~m}^{3}$ $+1.50 \mathrm{~m}^{3}-(2)\left(1.15 \mathrm{~m}^{3}\right)-(2)\left(0.12 \mathrm{~m}^{3}\right)=3.7 \mathrm{~m}^{3}$. The breached canisters and broken glass are at the bottom of the tube after the drop. Therefore, particles leaking from the canister into the tube would migrate very slowly to leak paths above the operating deck level. It is reasonable to assume that only a fraction of the particles will remain airborne long enough to travel the distance to the available leak paths, as there is no airflow within the tube. Particles will be removed through agglomeration, gravitational settiing, and plateout on surfaces. A maximum quasi-stable concentration for respirable particles in air following mechanical disturbance and time for settling is given as $100 \mathrm{mg}$ respirable particles $/ \mathrm{m}^{3}$ (NUREG/CR-2651, pp 2.58 and 2.66 [Nuclear Regulatory Commission [NRC] 1982]). The entire gas void volume of the tube is assumed to leave the confinement and enter the 
environment. With a void volume of $3.7 \mathrm{~m}^{3}$, the respirable particulate mass in this volume is therefore $3.7 \mathrm{~m}^{3} \times 100 \mathrm{mg} / \mathrm{m}^{3}=370 \mathrm{mg}$. This is taken to be the mitigated respirable source term released to the operating area. The onsite mitigated dose is calculated as:

$$
\begin{gathered}
\text { Dose }_{\text {onsite }}=(0.370 \mathrm{~g})\left(3.41 \times 10^{-2} \mathrm{~s} / \mathrm{m}^{3}\right)\left(3.3 \times 10^{-4} \mathrm{~m}^{3} / \mathrm{s}\right)\left(3.3 \times 10^{5} \mathrm{rem} / \mathrm{g}\right)= \\
1.37 \mathrm{rem}
\end{gathered}
$$

The mitigated doses are summarized in Table 4-4.

Table 4-4. Mitigated Dose Consequences for a Dropped Glass Canister Onto

\begin{tabular}{|c|c|c|c|}
\hline \multirow{2}{*}{ Receptor Location } & \multicolumn{2}{|c|}{$\begin{array}{c}\text { Point Source Without Stack or } \\
\text { Plume Meander }\end{array}$} & \multirow{2}{*}{$\begin{array}{l}\text { Guideline } \\
\text { mSv (rem) }\end{array}$} \\
\hline & $\begin{array}{l}x / Q \\
\left(\mathrm{~s} / \mathrm{m}^{3}\right)\end{array}$ & $\begin{array}{c}\text { EDE } \\
\text { mSv (rem) }\end{array}$ & \\
\hline $\begin{array}{l}\text { Onsite } \\
(100 \mathrm{~m} \mathrm{E})\end{array}$ & $3.41 \mathrm{E}-02$ & $\begin{array}{c}1.4 \mathrm{E}+01 \\
(1.4 \mathrm{E}+00 \mathrm{rem})\end{array}$ & $\begin{array}{c}5.0 E+01 \\
(5.0 \mathrm{E}+00 \text { rem })\end{array}$ \\
\hline $\begin{array}{c}\text { Hanford Site boundary } \\
(18.3 \mathrm{~km} \mathrm{E})\end{array}$ & $1.32 \mathrm{E}-05$ & $\begin{array}{c}5.3 \mathrm{E}-03 \\
(5.3 \mathrm{E}-04 \mathrm{rem})\end{array}$ & $\begin{array}{c}5.0 \mathrm{E}+00 \\
(5.0 \mathrm{E}-01 \text { rem })\end{array}$ \\
\hline $\begin{array}{l}\text { Near river bank } \\
(15.0 \mathrm{~km} \mathrm{E})\end{array}$ & $1.96 \mathrm{E}-05$ & $\begin{array}{c}7.9 \mathrm{E}-03 \\
(7.9 \mathrm{E}-04 \mathrm{rem})\end{array}$ & $\begin{array}{c}5.0 \mathrm{E}+00 \\
(5.0 \mathrm{E}-01 \mathrm{rem})\end{array}$ \\
\hline
\end{tabular}
Another Canister.

Note:
Hanford Company.

$E D E=$ effective dose equivalent

Comparison to Guidelines. If this accident is not mitigated or prevented by designed safety features, the radiological dose consequences exceed the onsite and offsite guidelines, assuming a probability of one for the accident. As the design of the CSB and the operations envisioned are at an early stage, no attempt is made to determine initiating event frequencies. Regardless of the frequency of the event, if still found to be credible in subsequent analyses, a structure, system of component would have to be designated as a least safety-significant because of the onsite consequences. (See Section 4.3 for safety-class and safety-significant criteria). At a probability of one for the event, a structure, system or component would need to be designated as safety-class. The mitigated consequences taking credit for the tube integrity and MHM tube seal, are within the onsite and offsite guidelines. Therefore, the impact absorbers should be designated as safetyclass, as in case of a drop of a canister, the impact absorbers would prevent a breach. As the tube and MHM tube seal contribute significantly to defensein-depth, they should be designated as safety-significant. To prevent an unfiltered release because of premature movement of the MHM while the glass canister has been partially lowered into the tube, the MHM interlocks and MHM/ valve turntable interlocks should be designated as safety-class. Also, the 
WHC-SD-WM-TI-781, Rev. 0

MHM should be seismically restrained to prevent canister shear during a seismic event when insertion/removal is taking place.

4.2.3.2 single Glass Canister Failure during Handling-MHN Drop. This is a similar accident as above, but one in which the tube is initially empty. Dropping a glass canister from the MHM into a tube is an operational accident caused by human error or equipment failure. The accident is classified as a containment failure.

Scenario Development. A MHM failure or human error during raising or lowering operations results in dropping a glass canister into an empty tube. The storage tube is not actively ventilated, although it will be vented via a cartridge filter to the operating area. Cooling is provided by natural convection that occurs through the vault. This natural convection flow is around the exterior of the tube, and is then exhausted through the CSB stack. The MHM will be in place over the tube when the drop occurs and the MHM tube seal is designed to maintain a seal for the tube. The glass canister could be sheared during MHM handling because of the lower shielding doors if the MHM inadvertently closed on the canister when it is partially in the MHM or by a bending moment applied to the canister because of differential movement between the MHM and the storage tube when the canister is partially in the tube and partially in the MHM. As the shear would be distributed over only a portion of the glass in the canister, the bounding scenario with the greater release of fines is the drop of the canister.

The canister is designed to withstand a drop of $7 \mathrm{~m}$ onto a $\mathrm{flat}$, essentially unyielding surface without breaching or dispersing radionuclides. The tube is designed to hold two large canisters, or three small canisters. Since a large canister contains a larger quantity of glass, the accident scenario assumes a large glass canister is dropped. The large canister is $4.5 \mathrm{~m}$ in height and the height of the drop is approximately $12.8 \mathrm{~m}$. The impact absorber at the bottom of the tube is designed to prevent a catastrophic canister failure. For this scenario, it is assumed the impact absorber is not in place, so the dropped canister is assumed to rupture and release airborne particulate from the shattered glass. The tube is initially not assumed to maintain its containment function so that releases from the canister enters the vault area or the CSB area. Particles suspended in the MHM-tube confinement are assumed to enter the building through breaches/unfiltered leak paths in the system.

Source Term Analysis. The inventory at risk is the total inventory of one large canister, or $2,735 \mathrm{~kg}$ of glass. The drop height is $12.8 \mathrm{~m}$, which considerably exceeds the $7 \mathrm{~m}$ the canisters are designed. Since this drop height exceeds the Farnsworth et al. (1988) drop tests of simulated HWVP glass from a $9 \mathrm{~m}(30 \mathrm{ft})$ height, a higher ARF could be anticipated for a $12.8 \mathrm{~m}$ drop. To estimate the amount of respirable particles produced in a drop of $12.8 \mathrm{~m}$, the methodology of NUREG-1320, Nuclear Fuel Cycle Facility Accident Analysis Handbook (NRC 1988) is used. Figure 4.11 of NUREG-1320 provides a graph in which the mass fraction of glass and ceramics produced as a function of effective impact energy density from crush-impact. A large glass canister holds approximately $2,735 \mathrm{~kg}$ of glass. Including the weight of the canister, 
the total weight is $3,402 \mathrm{~kg}$. The crush-impact energy for the dropped canister is calculated as:

$$
E=m g h=(3,402 \mathrm{~kg})\left(9.8 \mathrm{~m} / \mathrm{s}^{2}\right)(12.8 \mathrm{~m})=4.27 \times 10^{5} \mathrm{~J} .
$$

NUREG-1320 states that only one-half of the impact energy should be used to estimate the release fraction because of rebound and the fact that the substrate will absorb some of the impact energy. The volume of glass contained in a large canister is $2,735 \mathrm{~kg} / 2,640 \mathrm{~kg} / \mathrm{m}^{3}=1.03 \mathrm{~m}^{3}$, or $1.03 \mathrm{x}$ $10^{6} \mathrm{~cm}^{3}$. Therefore, the effective energy density is calculated as:

$$
\begin{gathered}
E / V=\left(4.27 \times 10^{5} \mathrm{~J} / 2\right)\left(1.0 \times 10^{7} \mathrm{ergs} / \mathrm{J}\right) /\left(1.03 \times 10^{6} \mathrm{~cm}^{3}\right)= \\
2.1 \times 10^{6} \mathrm{ergs} / \mathrm{cm}^{3}
\end{gathered}
$$

Figure 4.11 of NUREG-1320 assigns RFs only down to an effective energy density of $1.0 \times 10^{7} \mathrm{ergs} / \mathrm{cm}^{3}$, with $0.025 \mathrm{wt} \%$ for this energy density. While one could extrapolate the straight lines of Figure 4.11 down to $2.1 \mathrm{x}$ $10^{6} \mathrm{ergs} / \mathrm{cm}^{3}$, no attempt is done so, and the more conservative release fraction of $2.5 \times 10^{-4}$ is used. Applying this release fraction to $2,735 \mathrm{~kg}$ of glass, $684 \mathrm{~g}$ are released from the ruptured canister as respirable. No credit is taken for any source term reduction because of agglomeration, gravitational settling, and plateout on the surfaces.

Unmitigated Consequence Analysis. The released source term is used to determine the radiological doses to the onsite and offsite receptors. Using the relationship of:

$$
D=M \times \frac{X}{Q} \times R \times C
$$

The unmitigated onsite dose is carculated as:

$$
\begin{gathered}
\text { Dose }_{\text {onsite }}=(684 \mathrm{~g})\left(3.41 \times 10^{-2} \mathrm{~s} / \mathrm{m}^{3}\right)\left(3.3 \times 10^{-4} \mathrm{~m}^{3} / \mathrm{s}\right)\left(3.3 \times 10^{5} \mathrm{rem} / \mathrm{g}\right)= \\
2,540 \mathrm{rem}
\end{gathered}
$$

The unmitigated doses are summarized in Table 4-5. 
Table 4-5. Unmitigated Dose Consequences for a Dropped Glass Canister.

\begin{tabular}{|c|c|c|c|}
\hline \multirow{2}{*}{ Receptor Location } & \multicolumn{2}{|c|}{$\begin{array}{c}\text { Point Source Without Stack or } \\
\text { Plume Meander }\end{array}$} & \multirow{2}{*}{$\begin{array}{c}\text { Guidel ine } \\
\text { mSv (rem })\end{array}$} \\
\cline { 2 - 3 } & $\begin{array}{c}x / Q \\
\left(\mathrm{~s} / \mathrm{m}^{3}\right)\end{array}$ & $\begin{array}{c}\text { EDE } \\
\mathrm{mSv}(\mathrm{rem})\end{array}$ & \\
\hline $\begin{array}{c}\text { Onsite } \\
(100 \mathrm{~m} \mathrm{E})\end{array}$ & $3.41 \mathrm{E}-02$ & $\begin{array}{c}2.5 \mathrm{E}+04 \\
(2.5 \mathrm{E}+03 \mathrm{rem})\end{array}$ & $\begin{array}{c}5.0 \mathrm{E}+01 \\
(5.0 \mathrm{E}+00 \mathrm{rem})\end{array}$ \\
\hline $\begin{array}{c}\text { Hanford Site boundary } \\
(18.3 \mathrm{~km} \mathrm{E})\end{array}$ & $1.32 \mathrm{E}-05$ & $\begin{array}{c}9.8+00 \\
(9.8 \mathrm{E}-01 \mathrm{rem})\end{array}$ & $\begin{array}{c}5.0 \mathrm{E}+00 \\
(5.0 \mathrm{E}-01 \mathrm{rem})\end{array}$ \\
\hline $\begin{array}{c}\text { Near river bank } \\
(15.0 \mathrm{~km} \mathrm{E})\end{array}$ & $1.96 \mathrm{E}-05$ & $\begin{array}{c}1.5 \mathrm{E}+01 \\
(1.5 \mathrm{E}+00 \mathrm{rem})\end{array}$ & $\begin{array}{c}5.0 \mathrm{E}+00 \\
(5.0 \mathrm{E}-01 \mathrm{rem})\end{array}$ \\
\hline
\end{tabular}
Hanford Company.

EDE = effective dose equivalent

Mitigated Consequence Analysis. With the tube remaining intact and the MHM tube seal in place at the top of the tube, only a small amount of leakage is possible. The jnterior volume of an empty tube is $6.23 \mathrm{~m}^{3}$ and the volume of glass is $1.15 \mathrm{~m}^{3}$. The volume occupied by the large ruptured canister is approximately $0.12 \mathrm{~m}^{3}$. Therefore, the total void volume with in the tube is approximately $6.23 \mathrm{~m}^{3}-1.15 \mathrm{~m}^{3}-0.12 \mathrm{~m}^{3}=4.96 \mathrm{~m}^{3}$. The breached canister and broken $\mathrm{glass}$ is at the bottom of the tube after the drop. Therefore, particles leaking from the canister into the tube would migrate very slowly to leak paths above the operating deck level. It is reasonable to assume that only a fraction of the particles will remain airborne long enough to travel the distance from to the available leak paths, as there is no airflow within the tube. Particles will be removed through agglomeration, gravitational settling, and plateout on surfaces. A maximum quasi-stable concentration for respirable particles in air following mechanical djsturbance and time for settling is given as $100 \mathrm{mg}$ respirable particles $/ \mathrm{m}^{3}$ (NUREG/CR-2651, pp 2.58 and 2.66 [NRC 1982]). The entire gas void volume of the tube is assumed to leave the confinement and enter the environment. With a void volume of $4.96 \mathrm{~m}^{3}$, the respirable particulate mass in this volume is therefore $4.96 \mathrm{~m}^{3} \mathrm{x}$ $100 \mathrm{mg} / \mathrm{m}^{3}=496 \mathrm{mg}$. This is taken to be the mitigated respirable source term released to the operating area. The onsite mitigated dose is calculated as:

Dose $_{\text {onsite }}=(0.496 \mathrm{~g})\left(3.41 \times 10^{-2} \mathrm{~s} / \mathrm{m}^{3}\right)\left(3.3 \times 10^{-4} \mathrm{~m}^{3} / \mathrm{s}\right)\left(3.3 \times 10^{5} \mathrm{rem} / \mathrm{g}\right)=$ 1.84 rem

The mitigated doses are summarized in Table 4-6. 
WHC-SD-WM-TI-781, Rev. 0

Table 4-6. Mitigated Dose Consequences for a Dropped Glass Canister.

\begin{tabular}{|c|c|c|c|}
\hline \multirow{2}{*}{ Receptor Location } & \multicolumn{2}{|c|}{$\begin{array}{c}\text { Point Source Without Stack or } \\
\text { Plume Meander }\end{array}$} & \multirow{2}{*}{$\begin{array}{l}\text { Guidel ine } \\
\text { mSv (rem) }\end{array}$} \\
\hline & $\begin{array}{c}x / Q \\
\left(s / m^{3}\right)\end{array}$ & $\begin{array}{c}\text { EDE } \\
\mathrm{mSV} \text { (rem) }\end{array}$ & \\
\hline $\begin{array}{c}\text { Onsite } \\
(100 \mathrm{~m} \mathrm{E})\end{array}$ & $3.41 E-02$ & $\begin{array}{l}1.8 \mathrm{E}+01 \\
(1.8 \mathrm{E}-00 \text { rem })\end{array}$ & $\begin{array}{c}5.0 \mathrm{E}+01 \\
(5.0 \mathrm{E}+00 \mathrm{rem})\end{array}$ \\
\hline $\begin{array}{c}\text { Hanford Site boundary } \\
(18.3 \mathrm{~km} \mathrm{E})\end{array}$ & 1.32E-05 & $\begin{array}{c}7.1 \mathrm{E}-03 \\
(7.1 \mathrm{E}-04 \text { rem })\end{array}$ & $\begin{array}{c}5.0 \mathrm{E}+00 \\
(5.0 \mathrm{E}-01 \mathrm{rem})\end{array}$ \\
\hline $\begin{array}{l}\text { Near river bank } \\
(15.0 \mathrm{~km} \mathrm{E})\end{array}$ & $1.96 \mathrm{E}-05$ & $\begin{array}{c}1.1 \mathrm{E}-02 \\
\text { (1.1. } 03 \text { rem) }\end{array}$ & $\begin{array}{c}5.0 \mathrm{E}+00 \\
(5.0 \mathrm{E}-01 \mathrm{rem})\end{array}$ \\
\hline
\end{tabular}

Hate:

$E D E=$ effective dose equivalent

Had a small glass canister been involved in the rupture, with a volume of the glass at $0.74 \mathrm{~m}^{3}$ and the volume of the ruptured container at $0.12 \mathrm{~m}^{3}$, the resulting void volume would be $5.37 \mathrm{~m}^{3}$, resulting in a slightly higher mitigated consequence of $20 \mathrm{mSv}(2.0 \mathrm{rem})$ onsite.

Comparison to Guidelines. If this accident is not mitigated or prevented by designed safety features, the radiological dose consequences exceed the onsite and offsite guidelines, assuming a probability of one for the accident. As the design of the CSB and the operations envisioned are at an early stage, no attempt is made to determine initiating event frequencies. Regardless of the frequency of the event, if still found to be credible in subsequent analyses, a structure, system of component would have to be designated as at least safety-significant because of the onsite consequences. At a probability of one for the event, a structure, system or component would need to be designated as safety-class. Therefore, the impact absorber should be designated as safety-class, as in case of a drop of a canister, the impact absorber would prevent a breach. The mitigated consequences, taking credit for the tube integrity and MHM tube seal, are within the onsite and offsite guidelines. The tube and tube seal contribute significantly to defense-indepth and therefore should be designated as safety-significant. To prevent an unfiltered release because of premature movement of the MHM while the glass canister has been partially lowered into the tube, the MHM interlocks and MHM valve/turntable interlocks should be designated as safety-class. Also, the MHM should be seismically restrained to prevent canister shear during a seismic event when canister insertion/removal is taking place.

4.2.3.3 Glass Canister Pressure Release Due to Premature Weld Failure. A glass canister failure could be caused by pressure build-up within the canister because of premature failure of a weld joint during loss of canister cooling. This accident is classified as a containment failure. 
Scenario Development. It is not anticipated that a glass canister will be breached due to over-pressure caused by loss of cooling for the glass canister. However, if corrosion were to occur, or an undetected weld defect exists, the canister could be breached because of heat build-up inside the canister caused by the radioactive decay heating of the glass. For this scenario, it is assumed that one had occurred (corrosion and weld defect) after several years of storage and the canister did over-pressurize, and a release of fines within the canister resulted. The storage tube shield plug would normally be in place, which is designed to maintain a seal for the tube. The tube is initially not assumed to maintain its containment function so that the release from the canister enters the vault area or the CSB operating area. Particles suspended in the tube confinement area are assumed to enter the building through breaches/unfiltered leak paths in the system.

Source Term Analysis. As discussed in Section 4.2.3.1, Source Term Analysis, there exist the possibility that during cool-down of the glass, fines can be produced due to thermal stresses induced during normal cooling. Farnsworth et al. attributed 0.004 wt\% of particles less than $10 \mu \mathrm{m}$ diameter as primarily created before the impact, because of the cooling, With $2,735 \mathrm{~kg}$ of glass for a large canister, this would represent $2.735 \times 10^{6} \mathrm{~g} \times 4.0 \times$ $10^{-5}=109.4 \mathrm{~g}$ of glass particles (in powder form) less than $10 \mu \mathrm{m}$ that could be available for the pressurized release. It is assumed that these particles that are less than $10 \mu \mathrm{m}$ reside on the outer surfaces of the glass. With a mass of $2,735 \mathrm{~kg}$ of glass and density of $2,640 \mathrm{~kg} / \mathrm{m}^{3}$, the height of the glass inside the glass canister is $378.2 \mathrm{~cm}$. With a radius of $29.53 \mathrm{~cm}$ for the glass cylinder, the ratio of the top surface area to the total surface area of the glass cylinder is 0.036 . Therefore, $0.036 \times 109.4 \mathrm{~g}=3.94 \mathrm{~g}$ of particles less than $10 \mu \mathrm{m}$ would reside on the top surface of the glass.

NUREG/CR-3093, Aeroso7s Generated by Re7ease of Pressurized Powders and Solutions in Static Air (Sutter 1983) investigated the pressurized releasee of DUO and $\mathrm{TiO}_{2}$ powders from pressures from $50 \mathrm{psig}$ to $1000 \mathrm{psig.} \mathrm{The} \mathrm{average}$ largest fraction made airborne from the experiments was for $\mathrm{TiO}_{2}$ powder at 500 psig and resulted in $24.1 \%$ being made airborne. This ARF of 0.241 is used and with $3.94 \mathrm{~g}$ of glass particles at risk on the upper surface of the glass cylinder, $0.95 \mathrm{~g}$ of glass that is less than $10 \mu \mathrm{m}$ is expected to be released and made airborne.

Unmitigated Consequence Analysis. The released source term is used to determine the radiological doses to the onsite and offsite receptors. No credit is taken for any source term reduction because of agglomeration, gravitational settling, and plateout on the surfaces. Using the relationship

$$
D=M \times \frac{X}{Q} \times R \times C
$$

The unmitigated onsite dose is calculated as:

Dose $_{\text {onsite }}=(0.95 \mathrm{~g})\left(3.41 \times 10^{-2} \mathrm{~s} / \mathrm{m}^{3}\right)\left(3.3 \times 10^{-4} \mathrm{~m}^{3} / \mathrm{s}\right)\left(3.3 \times 10^{5} \mathrm{rem} / \mathrm{g}\right)=$ 
The unmitigated doses are summarized in Table 4-7.

Table 4-7. Unmitigated Dose Consequences for Glass Canister Over-Pressurization.

\begin{tabular}{|c|c|c|c|}
\hline \multirow{2}{*}{ Receptor Location } & \multicolumn{2}{|c|}{$\begin{array}{c}\text { Point Source Without Stack or } \\
\text { Plume Meander }\end{array}$} & \multirow{2}{*}{$\begin{array}{l}\text { Guidel ine } \\
\text { mSv (rem) }\end{array}$} \\
\hline & $\begin{array}{c}x / Q \\
\left(\mathrm{~s} / \mathrm{m}^{3}\right)\end{array}$ & $\begin{array}{c}\text { EDE } \\
\text { mSv (rem) }\end{array}$ & \\
\hline $\begin{array}{l}\text { Onsite } \\
(100 \mathrm{~m} \mathrm{E})\end{array}$ & $3.41 \mathrm{E}-02$ & $\begin{array}{l}3.5 E+01 \\
(3.5 E+00 \text { rem })\end{array}$ & $\begin{array}{c}5.0 \mathrm{E}+01 \\
(5.0 \mathrm{E}+00 \text { rem })\end{array}$ \\
\hline $\begin{array}{l}\text { Hanford Site boundary } \\
(18.3 \mathrm{~km} \mathrm{E})\end{array}$ & $1.32 \mathrm{E}-05$ & $\begin{array}{c}1.4 \mathrm{E}-02 \\
(1.4 \mathrm{E}-03 \text { rem) }\end{array}$ & $\begin{array}{c}5.0 \mathrm{E}+00 \\
(5.0 \mathrm{E}-01 \text { rem) }\end{array}$ \\
\hline $\begin{array}{l}\text { Near river bank } \\
(15.0 \mathrm{~km} \mathrm{E})\end{array}$ & $1.96 \mathrm{E}-05$ & $\begin{array}{c}2.0 \mathrm{E}-02 \\
(2.0 \mathrm{E}-03 \mathrm{rem})\end{array}$ & $\begin{array}{c}5.0 \mathrm{E}+00 \\
(5.0 \mathrm{E}-01 \text { rem) }\end{array}$ \\
\hline
\end{tabular}
Hanford Company.

$E D E$ = effective dose equivalent

Mitigated Consequence Analysis. With the tube remaining intact and the storage tube shield plug in place at the top of the tube, only a small amount of leakage is possible. The same discussion of Section 4.2.3.1, Mitigated Consequence Analysis, for the dropped glass canister applies for this scenario. The tube is assumed to contain a single large glass canister with the lower impact absorber $\left(\sim 0.21 \mathrm{~m}^{3}\right.$ volume $)$ in place. With a maximum quasistable concentration of $100 \mathrm{mg} / \mathrm{m}^{3}$, the mitigated consequences are slightly less than those for the dropped large glass canister, due to the reduced void volume $\left(4.73 \mathrm{~m}^{3}\right)$ with the shield plug in $\mathrm{pl}$ ace and the absence of the MHM cavity. The total void volume is $4.73 \mathrm{~m}^{3}-1.15 \mathrm{~m}^{3}-0.12 \mathrm{~m}^{3}-0.21 \mathrm{~m}^{3}=\sim 3.25$ $\mathrm{m}^{3}$ and the mitigated doses are slightly less than those of Table 4-4.

Comparison to Guidelines. The mitigated and unmitigated consequences for the onsite and offsite receptors are within the risk acceptance guidelines. However, as the unmitigated dose is significantly close to the guidelines and due to the uncertainties in the design and early analysis presented, it is prudent to designate the tube and storage tube shield plug as safety-significant.

\subsubsection{Cesium Container Failure. Dropping a cesium container during} unloading or during placement into the storage tube is an operational accident potentially caused by human error or equipment failure which could result in a failure of the cesium container. Other initiating events that could potentially result in catastrophic failure of a cesium container would be shearing the container because of inadvertently closing the MHM lower shielding doors during the process of raising or lowering the MCO or failure 
of the container because of external pressure caused by a hydrogen detonation in the storage tube.

Scenario Development. A MHM hoist failure or human error during materials handling could result in dropping a cesium container into the transport cask (during unloading) or into the storage tube. The drop that could cause the greatest damage to the cesium container would be into the storage tube (approximately $12.8 \mathrm{~m}$ ). It is assumed that the impact absorber normally placed at the bottom of the storage tube will prevent catastrophic failure of the cesium container. For this scenario it is assumed that, in addition to the drop of the container, the impact absorber has not been placed in the bottom of the storage tube. It is also conservatively assumed that, if the impact absorber is not in place, the storage tube would be breached by the drop of a cesium container. (Because the weight of the cesium container as proposed is much less than the weight of glass canisters, it might not breach the tube if dropped.)

The storage tube is not actively ventilated, although it witl be vented via a cartridge filter to the operating area. The MHM is assumed to be actively ventilated via a cartridge filter. For the bounding consequences of the accident, it is assumed that the storage tube and/or the MHM storage tube seal provides an unfiltered leak path for the respirable particles released from the cesium container.

The cesium container could be sheared during MHM handling because of the lower shielding doors of the MHM being inadvertently closed on the container when it is partially in the MHM or by a bending moment applied to the container because of differential movement between the MHM and the storage tube when the container is partially in the tube and partially in the MHM. The release from such an accident is assumed to be the same as the unmitigated release from the container drop with a direct leak path into the CSB operating area.

The final scenario with similar unmitigated and mitigated consequences to the container drop is the failure of the cesium container because of external pressure caused by a hydrogen detonation in the storage tube. (It is assumed that this accident would also fail the storage tube.) The hydrogen buildup could occur because of two extremely unlikely scenarios. One would be the radiolysis of water that had leaked into the storage tube. It is then assumed that the hydrogen could build up to a detonatable concentration, detonate, and cause the cesium container and the storage tube to breach. This scenario is extremely unlikely, because no internal sources of water are provided in the vault design. The second, even more unlikely scenario, is that the ion exchange resin would contain water, which would be subject to radiolysis. The hydrogen generated would then leak from the cesium container and be detonated in the storage tube.

Source Term Analysis. The inventory at $r i s k$ is the maximum radionuclide inventory of a cesium container, $3.2 \times 10^{3} \mathrm{Ci}$ of ${ }^{137} \mathrm{Cs}$. (For this accident, it is assumed that the resin has been dried; therefore it is assumed that no ion exchange liquid feed will be released.) It is assumed that $0.1 \%$ of the resin $(84 \mathrm{~kg} \times 0.001=84 \mathrm{~g})$ is in respirable particles. For the bounding case, all 
of this material is assumed to be released as respirable. Note that the unmitigated accident analys is envelopes a 11 accident consequences involving cesium containers in a single storage tube, including all drop accidents and all accidents that involve catastrophic failure of a single canister. Because the inventory of cesium postulated for this accident is the maximum allowable amount for a single storage tube, it is therefore the maximum amount of material that could be contained in a single cesium container. Because up to six cesium containers would fit into a storage tube, the amount of cesium in any combination of two containers involved in a drop accident would normally be expected to be less than the postulated amount.

Consequence Analysis. The released source term is used to determine the radiological doses to the onsite and offsite receptors. The following assumptions are used to determine the radiological consequences to human receptors.

- Only short-term exposure effects resulting from inhalation are evaluated.

- The values of $x / Q$ for the selected receptor locations are those given in Table 4-2 for releases without plume meander.

- The dose per unit of respirable radioactive material inhaled is $1.22 \times 10^{5} \mathrm{rem} / \mathrm{g}\left(3.2 \times 10^{5} \mathrm{Ci} /(84 \mathrm{~kg})\left(3.19 \times 10^{4} \mathrm{rem} / \mathrm{Ci}\right)\right.$.

Using the relationship

$$
D=M \times \frac{X}{Q} \times R \times C
$$

The unmitigated onsite dose is calculated as:

$$
\begin{gathered}
\text { Dose }_{\text {onșite }}=(84 \mathrm{~g})\left(3.41 \times 10^{-2} \mathrm{~s} / \mathrm{m}^{3}\right)\left(3.3 \times 10^{-4} \mathrm{~m}^{3} / \mathrm{s}\right)\left(1.22 \times 10^{5} \mathrm{rem} / \mathrm{g}\right)= \\
116 \mathrm{rem}
\end{gathered}
$$

The unmitigated doses are summarized in Table 4-8. 
WHC-SD-WM-TI-781, Rev. 0

Table 4-8. Unmitigated Dose Consequences for a Dropped Cesium Container.

\begin{tabular}{|c|c|c|c|}
\hline \multirow{2}{*}{ Receptor Location } & \multicolumn{2}{|c|}{$\begin{array}{c}\text { Point Source Without Stack or } \\
\text { Plume Meander }\end{array}$} & \multirow{2}{*}{$\begin{array}{c}\text { Guidel ine } \\
\text { mSv (rem })\end{array}$} \\
\cline { 2 - 3 } & $\begin{array}{c}\begin{array}{c}\mathrm{X} / \mathrm{Q} \\
\left(\mathrm{s} / \mathrm{m}^{3}\right)\end{array} \\
\begin{array}{c}\text { EDE } \\
\text { mSv (rem })\end{array}\end{array}$ & \\
\hline $\begin{array}{c}\text { Onsite } \\
(100 \mathrm{~m} \mathrm{E})\end{array}$ & $3.41 \mathrm{E}-02$ & $\begin{array}{c}1.2 \mathrm{E}+03 \\
(1.2 \mathrm{E}+02 \mathrm{rem})\end{array}$ & $\begin{array}{c}5.0 \mathrm{E}+01 \\
(5.0 \mathrm{E}+00 \mathrm{rem})\end{array}$ \\
\hline $\begin{array}{c}\text { Hanford Site boundary } \\
(18.3 \mathrm{~km} \mathrm{E})\end{array}$ & $1.32 \mathrm{E}-05$ & $\begin{array}{c}4.4 \mathrm{E}-01 \\
(4.4 \mathrm{E}-02 \mathrm{rem})\end{array}$ & $\begin{array}{c}5.0 \mathrm{E}+00 \\
(5.0 \mathrm{E}-01 \mathrm{rem})\end{array}$ \\
\hline $\begin{array}{c}\text { Near river bank } \\
(15.0 \mathrm{~km} \mathrm{E})\end{array}$ & $1.96 \mathrm{E}-05$ & $\begin{array}{c}6.6 \mathrm{E}-01 \\
(6.6 \mathrm{E}-02 \mathrm{rem})\end{array}$ & $\begin{array}{c}5.0 \mathrm{E}+00 \\
(5.0 \mathrm{E}-01 \mathrm{rem})\end{array}$ \\
\hline
\end{tabular}

Hanford Company.

EDE = effective dose equivalent

Mitigated Consequence Analysis. If the tube remained intact and the storage tube shield plug or MHM tube seal were in place at the top of the tube, only a small amount of leakage would be possible. The interior volume of an empty tube and MHM cavity is $6.23 \mathrm{~m}^{3}$ and that of the ion exchange resin container is $0.117 \mathrm{~m}_{3}^{3}$. Therefore, the total void volume within the tube is approximately $6.11 \mathrm{~m}^{3}$. The breached container is at the bottom of the tube after the drop. Therefore, particles leaking from the container into the tube would migrate very slowly to leak paths above the operating deck level. It is reasonable to assume that only a fraction of the particles will remain airborne long enough to travel the 9.5 - $12.8 \mathrm{~m}$ distance from the bottom of the tube to the available leak paths. Particles will be removed through agglomeration, gravitational settling, and plateout on surfaces. A maximum quasi-stable concentration for respirable particles in air following mechanical disturbance and time for settling is given as $100 \mathrm{mg}$ respirable particles $/ \mathrm{m}^{3}$ (NUREG/CR-2651, pp 2.58 and 2.66 [NRC 1982]). The entire gas void volume of the tube is assumed to leave the confinement and enter the environment. With a void volume of $3.25 \mathrm{~m}^{3}$, the respirable particulate mass in this volume is therefore $6.11 \mathrm{~m}^{3} \times 100 \mathrm{mg} / \mathrm{m}^{3}=611 \mathrm{mg}$. This is taken to be the mitigated respirable source term released to the operating area. The onsite mitigated dose is calculated as:

$$
\begin{gathered}
\text { Dose }_{\text {onsite }}=(0.611 \mathrm{~g})\left(3.41 \times 10^{-2} \mathrm{~s} / \mathrm{m}^{3}\right)\left(3.3 \times 10^{-4} \mathrm{~m}^{3} / \mathrm{s}\right)\left(1.22 \times 10^{5} \mathrm{rem} / \mathrm{g}\right)= \\
0.84 \mathrm{rem}
\end{gathered}
$$

The mitigated doses are summarized in Table 4-9. 
WHC-SD-WM-TI-781, Rev. 0

Table 4-9. Mitigated Dose Consequences for a Dropped Glass Canister.

\begin{tabular}{|c|c|c|c|}
\hline \multirow{2}{*}{ Receptor Location } & \multicolumn{2}{|c|}{$\begin{array}{c}\text { Point Source Without Stack or } \\
\text { Plume Meander }\end{array}$} & \multirow{2}{*}{$\begin{array}{l}\text { Guideline } \\
\text { mSv (rem) }\end{array}$} \\
\hline & $\begin{array}{c}x / Q \\
\left(s / m^{3}\right)\end{array}$ & $\begin{array}{c}\text { EDE } \\
\mathrm{mSv} \text { (rem) }\end{array}$ & \\
\hline $\begin{array}{l}\text { Onsite } \\
(100 \mathrm{~m} \mathrm{E})\end{array}$ & $3.41 \mathrm{E}-02$ & $\begin{array}{l}8.4 \mathrm{E}+00 \\
(8.4 \mathrm{E}-01 \text { rem) }\end{array}$ & $\begin{array}{c}5.0 \mathrm{E}+01 \\
(5.0 \mathrm{E}+00 \text { rem }) \\
\end{array}$ \\
\hline $\begin{array}{l}\text { Hanford Site boundary } \\
(18.3 \mathrm{~km} \mathrm{E})\end{array}$ & 1.32E-05 & $\begin{array}{l}3.2 \mathrm{E}-03 \\
(3.2 \mathrm{E}-04 \text { rem })\end{array}$ & $\begin{array}{c}5.0 \mathrm{E}+00 \\
(5.0 \mathrm{E}-01 \text { rem) }\end{array}$ \\
\hline $\begin{array}{l}\text { Near river bank } \\
(15.0 \mathrm{~km} \mathrm{E})\end{array}$ & $1.96 \mathrm{E}-05$ & $\begin{array}{c}4.8 \mathrm{E}-03 \\
(4.8 \mathrm{E}-04 \text { rem) }\end{array}$ & $\begin{array}{c}5.0 \mathrm{E}+00 \\
(5.0 \mathrm{E}-01 \text { rem) }\end{array}$ \\
\hline
\end{tabular}

Note: Guidelines are from WHC-CM-4-46, Nonreactor Facility Safety Analysis Manual, Westinghouse Hanford Company.

$E D E$ = effective dose equivalent

Comparison to Guidelines. If this accident is not mitigated or prevented by designed safety features, the radiological dose consequence exceed the onsite guidelines, assuming a probability of one for the accident. As the design of the CSB and the operations envisioned are at an early stage, no attempt is made to determine initiating event frequencies. Regardless of the frequency of the event, if still found to be credible in subsequent analyses, a structure, system of component would have to be designated as safety significant because of the onsite consequences. The mitigated consequences, taking credit for the tube integrity and storage tube shield plug, are within the onsite and offsite guidelines. Therefore, the tube and tube seal and MHM tube seal need to be designated as safety-significant for this accident. Furthermore, the impact absorber should be designated as safety-significant, because the impact absorber would prevent a breach of the storage tube (note that this equipment would be designated safety-class for accident scenarios involving the glass canisters). For accidents involving shearing a container, the preventive equipment is the set of interlocks on the MHM that prevent the lower shield doors from being shut while the container is partway out of the MHM and the set of interlocks that prevent MHM lateral movement during the lowering of or raising of cesium containers. This equipment would be designated safety significant on the basis of this accident scenario. For the hydrogen detonation accident, administrative controls which prevent the buildup of hydrogen in the storage tube to a detonatable concentration should be developed. These include a surveillance routine that would reliably detect the presence of hydrogen or moisture in the storage tube (because of the in-leakage of water) and controls to assure that cesium ion exchange resin stored in the cesium containers is completely dried.

4.2.3.5 Cesium Container Pressurized Release. It is specified in the request for proposal (RFP) that the ion exchange resin in the cesium container will be dried to eliminate the possibility of gas generation or the presence of free liquids. This section assumes that, because of a failure of administrative 
controls, a cesium container containing a volume of ion exchange process feed equal to the volume of water that is present with the ion exchange resin as received from the vendor is inadvertently sent to the CSB for storage. This could result in either an internal hydrogen detonation or a pressurized release because of overheating the container and generating steam. The consequences of the two scenarios are assumed to be similar.

Scenario Development. Because of a breakdown of administrative controls, a cesium container is sent to the CSB for storage containing fully loaded ion exchange resin that has not been dried. In addition to the fully loaded resin, the container has a volume of ion exchange feed (concentrations of radionuclides as per Table 3-4), equal to the volume of the 10 weight percent water $(8.4 \mathrm{~kg})$ that the resin would contain as received from the vendor. It is assumed that, because of a loss of cooling in either the MHM or the storage tube, the container fails and steam with entrained radionuclides and resin particies is discharged from the a breach in the container. The material would then be discharged to either the storage tube or the MHM.

The storage tube is not actively ventilated, although it will be vented via a cartridge filter to the operating area. The MHM is assumed to be actively ventilated via a cartridge filter. For the bounding consequences of the accident, it is assumed that the storage tube and/or the MHM storage tube seal provides an unfiltered leak path for the respirable particles released from the cesium container.

Source Term Analysis. The inventory at risk is the maximum radionuclide inventory of a cesium container, $3.2 \times 10^{5} \mathrm{Cj}$ of ${ }^{137} \mathrm{Cs}$ and 8.41 iters of ion exchange feed. It is assumed that $0.1 \%$ of the resin $(84 \mathrm{~kg} \times 0.001=84 \mathrm{~g})$ is in less than ten micron particles. Per Sutter, 1983, a pressurized release of titanium oxide at $500 \mathrm{psi}$ has an ARF of 4.5 percent. Thus, the amount of ion exchange resin assumed to be released in respirable form is 4.5 percent of the respirable amount $(0.045 \times 84 \mathrm{~g}=3.78 \mathrm{~g})$. For the release of $i$ on exchange feed, a bounding ARF of $1.0 \times 10^{-1}$ and RF of 0.7 for highly superheated liquid are used, per DOE-HDBK-3010-94 (Mishima 1994), Section 3. The total amount of ion exchange feed released is then $0.588 \mathrm{~L}(0.1 \times 0.7 \times 8.41$ iter $)$.

Consequence Analysis. The released source term is used to determine the radiological doses to the onsite and offsite receptors. The following assumptions are used to determine the radiological consequences to human receptors.

- Only short-term exposure effects resulting from inhalation are evaluated.

- The values of $\chi / Q$ for the selected receptor locations are those given in Table 4-2 for releases without plume meander.

- The dose per unit of respirable radioactive material inhaled is $1.22 \times 10^{5} \mathrm{rem} / \mathrm{g}\left(3.2 \times 10^{5} \mathrm{Ci} /(84 \mathrm{~kg})\left(3.19 \times 10^{4} \mathrm{rem} / \mathrm{Ci}\right)\right.$ for $i o n$ exchange resign. The dose per unit of respirable aerosol from ion exchange feed is $1.8 \times 10^{4} \mathrm{rem} / \mathrm{L}\left[6.8 \times 10^{4} \mathrm{rem} / \mathrm{gal} /(3.79 \mathrm{~L} / \mathrm{gal})\right]$. 
WHC-SD-WM-TI-781, Rev. 0

Using the relationship

$$
D=M \times \frac{X}{Q} \times R \times C
$$

The unmitigated onsite dose from the pressurized release of resin is calculated as:

Dose $_{\text {onsite }}=(3.78 \mathrm{~g})\left(3.41 \times 10^{-2} \mathrm{~s} / \mathrm{m}^{3}\right)\left(3.3 \times 10^{-4} \mathrm{~m}^{3} / \mathrm{s}\right)\left(1.22 \times 10^{5} \mathrm{rem} / \mathrm{g}\right)=$

$$
5.19 \mathrm{rem}
$$

The unmitigated onsite dose from the pressurized release of ion exchange feed is calculated as:

Dose $_{\text {onsite }}=(0.588 \mathrm{~L})\left(3.41 \times 10^{-2} \mathrm{~s} / \mathrm{m}^{3}\right)\left(3.3 \times 10^{-4} \mathrm{~m}^{3} / \mathrm{s}\right)\left(1.79 \times 10^{4} \mathrm{rem} / \mathrm{L}\right)=$ $0.12 \mathrm{rem}$

The total unmitigated dose is then $5.31 \mathrm{rem}$. The unmitigated doses are summarized in Table 4-10. 
WHC-SD-WM-TI-781, Rev. 0

Table 4-10. Unmitigated Dose Consequences for a Pressurized Release from a Cesium Container.

\begin{tabular}{|c|c|c|c|}
\hline \multirow{2}{*}{ Receptor Location } & \multicolumn{2}{|c|}{$\begin{array}{c}\text { Point Source Without Stack or } \\
\text { Plume Meander }\end{array}$} & \multirow{2}{*}{$\begin{array}{l}\text { Guidel ine } \\
\text { mSv (rem) }\end{array}$} \\
\hline & $\begin{array}{l}X / Q \\
\left(s / m^{3}\right)\end{array}$ & $\begin{array}{c}\text { EDE } \\
\mathrm{mSv} \text { (rem) }\end{array}$ & \\
\hline $\begin{array}{l}\text { Onsite } \\
(100 \mathrm{~m} \mathrm{E})\end{array}$ & $3.41 \mathrm{E}-02$ & $\begin{array}{c}5.3 \mathrm{E}+01 \\
(5.3 \mathrm{E}+00 \text { rem })\end{array}$ & $\begin{array}{c}5.0 \mathrm{E}+01 \\
(5.0 \mathrm{E}+00 \mathrm{rem})\end{array}$ \\
\hline $\begin{array}{l}\text { Hanford Site boundary } \\
(18.3 \mathrm{~km} \mathrm{E})\end{array}$ & $1.32 \mathrm{E}-05$ & $\begin{array}{c}2.0 \mathrm{E}-02 \\
(2.0 \mathrm{E}-03 \text { rem })\end{array}$ & $\begin{array}{c}5.0 \mathrm{E}+00 \\
(5.0 \mathrm{E}-01 \text { rem })\end{array}$ \\
\hline $\begin{array}{l}\text { Near river bank } \\
(15.0 \mathrm{~km} \mathrm{E})\end{array}$ & $1.96 \mathrm{E}-05$ & $\begin{array}{c}3.0 \mathrm{E}-02 \\
(3.0 \mathrm{E}-03 \text { rem) }\end{array}$ & $\begin{array}{c}5.0 \mathrm{E}+00 \\
(5.0 \mathrm{E}-01 \text { rem) }\end{array}$ \\
\hline
\end{tabular}

Hanford Company.

$E D E=$ effective dose equivalent

Mitigated Consequence Analysis. If the release occurred from a canister in a storage tube, an even, smaller release would occur. The interior volume of an empty tube is $4.73 \mathrm{~m}^{3}$ and that of the ion exchange resin container is $0.117 \mathrm{~m}^{3}$. The lower impact absorber volume is $-0.21 \mathrm{~m}^{3}$. Therefore, the total void volume within the tube is approximately $4.40 \mathrm{~m}^{3}$. Particles and aerosol leaking from the container into the tube would migrate very slowly to leak paths above the operating deck level. It is reasonable to assume that only a fraction of the particles and aerosol will remain airborne long enough to escape from the tube via the available leakpaths. Particles will be removed through agglomeration, gravitational settling, and plateout on surfaces. A maximum quasi-stable concentration for respirable particles in air following mechanical disturbance and time for settling is given as $100 \mathrm{mg}$ respirable particles $/ \mathrm{m}^{3}$ (NUREG/CR-2651, pp 2.58 and 2.66 [NRC 1982]). The entire gas void volume of the tube is assumed to leave the confinement and enter the environment. With a void volume of $4.40 \mathrm{~m}^{3}$, the respirable particulate mass in this volume is therefore $4.40 \mathrm{~m}^{3} \times 100 \mathrm{mg} / \mathrm{m}^{3}=440 \mathrm{mg}$. This is taken to be the mitigated respirable source term released to the operating area. The 440 mg could be composed of a combination of ion exchange resin fines with a unit dose of $1.22 \times 10^{5} \mathrm{rem} / \mathrm{g}$ and the ion exchange feed solution with a unit dose of $1.8 \times 10^{1} \mathrm{rem} / \mathrm{g}$ [Conservative]y assuming a density of $1,000 \mathrm{~g} / 1 \mathrm{iter}$, the unit dose is $\left.1.8 \times 10^{4} \mathrm{rem} / 1 \mathrm{iter} /(1,000 \mathrm{~g} / 1 \mathrm{iter})=1.8 \mathrm{rem} / \mathrm{g}\right]$. If it is conservatively assumed that all the released material is ion exchange resin, the onsite mitigated dose is calculated as:

$$
\begin{gathered}
\text { Dose }_{\text {onsite }}=(0.440 \mathrm{~g})\left(3.41 \times 10^{-2} \mathrm{~s} / \mathrm{m}^{3}\right)\left(3.3 \times 10^{-4} \mathrm{~m}^{3} / \mathrm{s}\right)\left(1.22 \times 10^{5} \mathrm{rem} / \mathrm{g}\right)= \\
0.60 \mathrm{rem}
\end{gathered}
$$

The mitigated doses are summarized in Table 4-11. 
Table 4-11. Mitigated Dose Consequences for a Pressurized Release from a Canister.

\begin{tabular}{|c|c|c|c|}
\hline \multirow{2}{*}{ Receptor Location } & \multicolumn{2}{|c|}{$\begin{array}{c}\text { Point Source Without Stack or } \\
\text { Plume Meander }\end{array}$} & \multirow{2}{*}{$\begin{array}{l}\text { Guideline } \\
\text { mSv (rem) }\end{array}$} \\
\hline & $\begin{array}{c}x / Q \\
\left(s / m^{3}\right)\end{array}$ & $\begin{array}{c}\text { EDE } \\
\mathrm{mSv}(\text { rem) }\end{array}$ & \\
\hline $\begin{array}{c}\text { Onsite } \\
(100 \mathrm{~m} \mathrm{E})\end{array}$ & $3.41 E-02$ & $\begin{array}{c}6.0 \mathrm{E}+00 \\
(6.0 \mathrm{E}-01 \text { rem) }\end{array}$ & $\begin{array}{c}\text { 5. } 0 \mathrm{E}+01 \\
(5.0 \mathrm{E}+00 \text { rem })\end{array}$ \\
\hline $\begin{array}{c}\text { Hanford Site boundary } \\
(18.3 \mathrm{~km} \mathrm{E})\end{array}$ & $1.32 \mathrm{E}-05$ & $\begin{array}{c}2.3 \mathrm{E}-03 \\
(2.3 \mathrm{E}-04 \text { rem) }\end{array}$ & $\begin{array}{c}5.0 \mathrm{E}+00 \\
(5.0 \mathrm{E}-01 \text { rem) }\end{array}$ \\
\hline $\begin{array}{l}\text { Near river bank } \\
(15.0 \mathrm{~km} \mathrm{E})\end{array}$ & $1.96 \mathrm{E}-05$ & $\begin{array}{c}3.5 \mathrm{E}-03 \\
(3.5 \mathrm{E}-04 \text { rem) }\end{array}$ & $\begin{array}{l}5.0 \mathrm{E}+00 \\
(5.0 \mathrm{E}-01 \mathrm{rem})\end{array}$ \\
\hline
\end{tabular}

Note: Guidel ines are from WHC-CM-4-46, Nonreactor Facility Safety Analys is Manual, Westinghouse Hanford Company.

$E D E=$ effective dose equivalent

The doses from a pressurized release into an MHM would be less because of the lower volume of the MHM. Furthermore, the MHM will be equipped with a high-efficiency particulate air-filtered ventilation system. If the high efficiency particulate air filters could withstand the pressurization, the release would be further mitigated.

Comparison to Guidelines. If this accident is not mitigated or prevented by designed safety features, the radiological dose consequence could exceed the onsite guidelines, assuming a probability of one for the accident. When the design of the CSB and the operations envisioned are at an early stage, no attempt is made to determine initiating event frequencies. The mitigated consequences, taking credit for the tube integrity and storage tube shield plug, are within the onsite and offsite guidelines. Therefore, the tube and tube seal need to be designated as safety-significant for this accident. Furthermore, the MHM confinement should be designated as safetysignificant (note that this equipment would be designated safety class for accident scenarios involving the glass canisters). In addition, the preventive features for this scenario are the administrative control requiring removal of water from the resin before it is stored in the CSB and the cooling of the storage tubes and the MHM (for the overpressurization because of steam formation if water is present).

\subsection{SAFETY CLASSIFICATION SUMMARY}

Safety class determinations in this document are in accordance with the criteria and requirements of Section 9.0 of WHC-CM-4-46, Safety Analysis Manual. The two safety designations are: 1) safety-class, and 2) safetysignificant. The selection of safety-class and safety-significant SSCs is based primarily on their particular importance to defense-in-depth. Safetyclass SSCs prevent or mitigate releases to the public that would otherwise 
exceed the offsite radiological risk guideline, or prevent accidental nuclear criticality. Safety-significant SSCs prevent or mitigate releases of radiological materials to onsite workers and toxic chemicals to the offsite public and onsite workers.

Table 1 in Chapter 9 of WHC-CM-4-46 shows the previous SSC designations as compared to the current safety-class and safety-significant. These comparisons are reproduced in Table 4-12.

Table 4-12. Safety Systems, Structures, and Components Criteria. (2 sheets)

\begin{tabular}{|c|c|c|}
\hline Safety Structures, systems, and Components (SSCs): & $\begin{array}{l}\text { Previous SSC } \\
\text { Designation* }\end{array}$ & $\begin{array}{c}\text { New SSC } \\
\text { Designation }\end{array}$ \\
\hline $\begin{array}{l}\text { Prevent or mitigate offsite public exposure in excess of } 500 \text { mrem ( } 5 \\
\text { mSV) EDE. See Notes } 1 \text { and } 2 \text {. }\end{array}$ & SC-1 & Safety class \\
\hline $\begin{array}{l}\text { Place or maintain an operating process in a safe condition that prevents } \\
\text { or mitigates consequences to the public in excess } 500 \mathrm{mrem} \text { EDE. See } \\
\text { Note } 1 \text {. }\end{array}$ & SC-1 & Safety class \\
\hline $\begin{array}{l}\text { Monitor the release of radioactive materials to the environment during } \\
\text { and after accidents where the monitor's output initiates Emergency } \\
\text { Response plan actions or operator actions to place the operating process } \\
\text { in a safe condition per Criterion } 2 \text {. }\end{array}$ & sc- 1 & Safety class \\
\hline $\begin{array}{l}\text { Maintain operating parameters within the TSRs or OSRs that protect the } \\
\text { public per Criteria } 1 \text { or } 2 \text {. }\end{array}$ & $s c-1$ & Safety class \\
\hline $\begin{array}{l}\text { Maintain double contingency protection against an accidental nuclear } \\
\text { criticality as defined in WHC-CM-4-29. Nuclear Criticality Safety. }\end{array}$ & sc- 1 & Safety class \\
\hline $\begin{array}{l}\text { Prevent or mitigate onsite exposure to radiological materials in excess } \\
\text { of } 5 \mathrm{rem}(50 \mathrm{mSV}) \mathrm{EDE} \text {. See Notes } 1 \text { and } 2 \text {. }\end{array}$ & $\mathrm{sc}-2$ & $\begin{array}{l}\text { Safety } \\
\text { significant }\end{array}$ \\
\hline $\begin{array}{l}\text { Prevent or mitigate toxic chemical exposure to within the risk } \\
\text { guidel ines of WHC-CM-4-46, Chapter } 7.0 \text {. See Notes } 2 \text { and } 4 \text {. }\end{array}$ & sc- 1 or sc- 2 & $\begin{array}{l}\text { Safety } \\
\text { significant }\end{array}$ \\
\hline $\begin{array}{l}\text { Place or maintain an operating process in a safe condition that prevents } \\
\text { or mitigates consequences that exceed Criteria } 6 \text { or } 7 \text {. }\end{array}$ & $\mathrm{SC}-1$ or $\mathrm{SC}-2$ & $\begin{array}{l}\text { Safety } \\
\text { significant }\end{array}$ \\
\hline $\begin{array}{l}\text { Prevent or mitigate exposure in excess of } 5 \text { rem EDE or an airborne } \\
\text { concentration of toxic material in excess of the applicable chemical } \\
\text { ERPG-2 limit to facility operators who are relied on to achieve the safe } \\
\text { condition of Criteria } 2 \text { and } 8 \text {. }\end{array}$ & sc- -1 or $\mathrm{sc}-2$ & $\begin{array}{l}\text { Safety } \\
\text { significant }\end{array}$ \\
\hline $\begin{array}{l}\text { Monitor the release of radioactive and/or hazardous materials to the } \\
\text { environment during and after accidents where the monitor's output } \\
\text { initiates Emergency Response Plan actions or operator actions to place } \\
\text { the operating process in a safe condition per Criterion } 8 \text {. }\end{array}$ & SC-1 or SC-2 & $\begin{array}{l}\text { Safety } \\
\text { significant }\end{array}$ \\
\hline $\begin{array}{l}\text { Maintain operating parameters within the ISRs or OSRs that protect the } \\
\text { onsite worker per criterion } 6 \text {. }\end{array}$ & sc-2 & $\begin{array}{l}\text { Safety } \\
\text { significant }\end{array}$ \\
\hline $\begin{array}{l}\text { Provide defense-in-depth prevention or mitigation of an uncontrolled } \\
\text { release of radioactive and/or hazardous material deemed significant. } \\
\text { See Hote } 4 \text {. }\end{array}$ & $N / A$ & $\begin{array}{l}\text { Safety } \\
\text { significant }\end{array}$ \\
\hline $\begin{array}{l}\text { Prevent or mitigate an acute fatality to a facility worker or serious } \\
\text { injury to a group of workers, except where the sscs are controlled } \\
\text { through an implemented institutional safety or radiation protection } \\
\text { program. }\end{array}$ & $s c-3$ & $\begin{array}{l}\text { Safety } \\
\text { significant }\end{array}$ \\
\hline $\begin{array}{l}\text { Support the safety function of a safety class SSC. This includes } \\
\text { control and monitoring functions (operating air, electrical power, } \\
\text { instrumentation, etc.). See Note } 3 \text {. }\end{array}$ & SC- 1 & Safety class \\
\hline
\end{tabular}




\begin{tabular}{|c|c|c|}
\hline Safety Structures, Systems, and Components (SSCs): & $\begin{array}{c}\text { Previous SSC } \\
\text { Designation* }\end{array}$ & $\begin{array}{c}\text { New SSC } \\
\text { Designation }\end{array}$ \\
\hline $\begin{array}{l}\text { Support the safety function of a safety significant SSC. This includes } \\
\text { control and monitoring functions coperating air, electrical power, } \\
\text { instrumentation, etc.). See Notes } 3 \text { and 4. }\end{array}$ & SC-1 or sC-2 & Safety \\
significant \\
\hline
\end{tabular}

* No longer applies to the designation of SSCs; used for existing SELs and reference documentation until they are revised.

$\begin{array}{lll}\text { EDE } & = & \text { effective dose equivalent } \\ \text { ERPG } & = & \text { Emergency Response Planning Guidel ines } \\ \text { OSR } & = & \text { Operational Safety Requirements } \\ \text { TSR } & = & \text { Technical Safety Requirement }\end{array}$

NOTES:

1. Do not include ingestion as a radiological dose pathway. When the initiating event is a a) natural phenomena hazard, b) specific equipment failure, or c) specific failure mode, where the associated frequency is supported by adequate data to make the safety analysis uncertainties small, use the consequence threshold of the radiological risk guidelines of WHC-CM-4-46, Chapter 7.0. consider initiating events with a frequency greater than $10^{-1}$ per year to be planned events and mitigate their consequences to within normal operational limits.

2. Where a postulated accident can cause multiple system failures, evaluate bounding consequences at a common receptor location. Select safety SSCs and determine residual consequences for the purpose of designating other structures or systems.

3. SSCs that may prevent the adequate function of safety SSCs through physical interaction (seismic, pipe whip, jet impingement, water damage, environmental changes, etc.) are considered to be safety significant. See Appendix A, paragraph $3 . e$ of WHC-CM-4-46.

4. Water treatment systems that use chlorine are considered to pose a risk commonly accepted by the public, provided that their design is consistent with public water treatment plants. Do not designate such systems as safety class or safety significant.

As a result of the postulated accidents analyzed, Table 4-13 summarizes the structures, systems, and components (SSCs) that are candidates for safetyclass or safety-significant designation. There are no new designations required because of the handling and storage of glass or cesium containers, beyond those envisioned for SNF storage. However, if a container were to rupture while in a tube, special recovery procedures may be required to stabilized the situation, and to recover and process the large quantity of fines, to allow final disposal of the materiat. 
Table 4-13. Preliminary List of CSB Safety-Class and Safety-Significant SSCs.

\begin{tabular}{|c|c|c|c|}
\hline $\begin{array}{l}\text { structure, System or } \\
\text { Component }\end{array}$ & Safety Function & Referenced Accident Analysis & $\begin{array}{c}\text { Safety } \\
\text { Classification }\end{array}$ \\
\hline Storage tubes & Conf inement of releases & $\begin{array}{l}\text { Over-pressurization during } \\
\text { handling. } \\
\text { single canister failure } \\
\text { during handling. Multiple } \\
\text { failure during handling. }\end{array}$ & Safety-significant \\
\hline MHM & Confinement of releases & $\begin{array}{l}\text { Over-pressurization during } \\
\text { handling }\end{array}$ & $\begin{array}{l}\text { Sofety- } \\
\text { significant }\end{array}$ \\
\hline MHM interlocks & $\begin{array}{l}\text { Prevent inadvertent мнM } \\
\text { motion while the canister } \\
\text { is being inserted into or } \\
\text { withdrawn from a tube }\end{array}$ & $\begin{array}{l}\text { Single canister failure } \\
\text { during handling - lateral } \\
\text { forces. }\end{array}$ & Safety-class \\
\hline $\begin{array}{l}\text { MHM/valve turntable } \\
\text { interlock }\end{array}$ & $\begin{array}{l}\text { Prevent inadvertent floor } \\
\text { valve closure while } \\
\text { canister is in } \\
\text { intermediate position }\end{array}$ & $\begin{array}{l}\text { single canister failure } \\
\text { during handling - lateral } \\
\text { forces. }\end{array}$ & Safety-class \\
\hline Impact absorbers & $\begin{array}{l}\text { Prevent catastrophic } \\
\text { failure of canister if } \\
\text { dropped to the botton of } \\
\text { the tube; protect } \\
\text { confinement function } \\
\text { Prevent failure of both } \\
\text { canisters if one is } \\
\text { dropped on another }\end{array}$ & $\begin{array}{l}\text { Single canister failure } \\
\text { during handing. } \\
\text { Multiple canister failure } \\
\text { during handling. }\end{array}$ & Safety-class \\
\hline
\end{tabular}

$\begin{array}{lll}\text { CBS } & = & \text { Canister storage Building } \\ \text { MHM } & = & \text { MCO handl ing machine } \\ \text { SSC } & = & \text { structures, systems, and components }\end{array}$

\subsection{HAZARD CLASSIFICATION EVALUATION}

The hazard classification for the CSB for SNF operations has been determined to be a Hazard Category 2 facility using the guidance of D0E-STD-1027-92, Hazard Categorization and Accident Analysis Techniques for Compliance with DOE Order 5480.23, Nuclear Safety Analysis Reports (DOE 1992). The final hazard category for the CSB was derived in WHC-SD-SNF-HC-007, Hazard Category Analysis for the Canister Storage Building (Kummerer 1995). That document was prepared in accordance with WHC-CM-4-46, Section 4.0, "Determining and Documenting Facility Hazard Category", the WHC guide for implementing and documenting the requirements of DOE Order 5480.23 and DOE-STD-1027-92. This hazard classification assignment for the CSB has been approved by DOE (Sellers 1996). The final hazard categorization for the SNF was based upon a beyond design basis earthquake in which the CSB operating, area floor collapsed and al1 390 MCOs were breached. A total of $2.56 \times 10^{6} \mathrm{~g}$ of fuel in fines form at risk for release (not all released), and the sum of the ratios was determined to be 19.0 when compared to the Hazard Category 2 threshold quantity (TQ) value. 
For a preliminary hazard categorization of the glass and cesium canisters, the three cases of Section 3.0 were examined. For Case A, with 678 standard canisters, $1.1 \times 10^{6} \mathrm{~kg}$ of glass would be the inventory. For Case $B$, with 452 large canisters, $1.2 \times 10^{6} \mathrm{~kg}$ of glass would be the inventory. Since there is a limit of $3.2 \times 10^{5} \mathrm{Ci}$ of ${ }^{137} \mathrm{Cs}$ per storage tube and with 226 tubes per vault, Case B provides a higher inventory than Case C. Table 5-1 provides the sum of the ratios for a single large glass canister (Case B), using the methodology of DOE-STD-1027-92 for a preliminary hazard categorization and comparing the sum of the ratios to the Hazard Category 2 TQ value. For those isotopes not listed in Table A.l of the Standard, a determination was made whether the isotope was a beta-gamma emitter, mixed fission product, or alpha emitter, and the recommended TQ 2 value used from Table A.l for the particular isotope.

Table 5-1. Preliminary Hazard Categorization For One Large Glass Canister. (2 sheets)

\begin{tabular}{|c|c|c|c|c|}
\hline Isotope & $\mathrm{Ci} / \mathrm{kg}$ & Ci/Large Canister & Cat. 2 TQ & $\begin{array}{c}\text { Ratio (Ci of } \\
\text { Isotope/Cat. } 2 \text { Ta) }\end{array}$ \\
\hline${ }^{55} \mathrm{Fe}$ & $1.60 E-02$ & $4.38 \mathrm{E}+01$ & $1.10 E+07$ & $3.98 E-06$ \\
\hline${ }^{59} \mathrm{Ni}$ & $2.30 \mathrm{E}-04$ & $6.29 E-01$ & $2.50 E+06$ & $2.52 \mathrm{E}-07$ \\
\hline${ }^{60} \mathrm{Co}$ & $4.80 E-02$ & $1.31 \mathrm{E}+02$ & $1.90 \mathrm{E}+05$ & $6.91 E-04$ \\
\hline${ }^{63} \mathrm{Ni}$ & $2.60 \mathrm{E}-02$ & $7.11 E+01$ & $4.50 \mathrm{E}+06$ & $1.58 \mathrm{E}-05$ \\
\hline${ }^{\prime \prime} \mathrm{Se}$ & $6.80 E-06$ & $1.86 E-02$ & $4.30 E+05$ & $4.33 E-08$ \\
\hline${ }^{90} \mathrm{Sr}$ & $5.00 E+01$ & $1.37 E+05$ & $2.20 E+04$ & $6.22 E+00$ \\
\hline${ }^{90} \mathrm{Y}$ & $5.00 E+01$ & $1.37 \mathrm{E}+05$ & $x x$ & $x x$ \\
\hline${ }^{93 \mathrm{~m}} \mathrm{Nb}$ & $1.40 E-03$ & $3.83 E+00$ & $2.50 E+06$ & $1.53 \mathrm{E}-06$ \\
\hline${ }^{93} \mathrm{Zr}$ & $2.30 \mathrm{E}-03$ & $6.29 E+00$ & $8.90 E+04$ & $7.07 \mathrm{E}-05$ \\
\hline${ }^{99} \mathbf{T C}$ & $7.30 \mathrm{E}-02$ & $2.00 E+02$ & $3.80 \mathrm{E}+06$ & $5.25 E-05$ \\
\hline${ }^{106} \mathrm{Ru}$ & $3.205-03$ & $8.75 \varepsilon+00$ & $6.50 E+03$ & $1.35 \mathrm{E}-03$ \\
\hline${ }^{106} \mathrm{Rh}$ & $3.20 E-03$ & $8.75 E+00$ & $x x$ & $x x$ \\
\hline${ }^{107} \mathrm{Pd}$ & $6.50 E-05$ & $1.78 E-01$ & $4.30 E+05$ & 4.13E- 07 \\
\hline${ }^{1100 \mathrm{Ag}} \mathrm{Ag}$ & $1.60 \mathrm{E}-07$ & $4.38 E-04$ & $5.30 E+05$ & $8.26 E-10$ \\
\hline${ }^{113 m} \mathrm{Cd}$ & $1.80 E-02$ & $4.92 E+01$ & $4.30 E+05$ & $1.14 \mathrm{E}-04$ \\
\hline${ }^{112 \mathrm{~m}} \mathrm{In}$ & $3.00 E-05$ & $8.21 E-02$ & $x x$ & $x x$ \\
\hline${ }^{113} \mathrm{Sn}$ & $3.00 \mathrm{E}-05$ & $8.21 E-02$ & $3.20 \mathrm{E}+06$ & $2.56 E-08$ \\
\hline${ }_{11 \sin } \mathrm{Cd}$ & 1.10E-08 & $3.01 E-05$ & 4.30E+05 & $7.00 \mathrm{E}-11$ \\
\hline${ }^{119 m} \mathrm{Sn}$ & $1.60 E-07$ & $4.38 E-04$ & $2.50 E+06$ & $1.75 \mathrm{E}-10$ \\
\hline${ }^{121 \mathrm{~m}} \mathrm{Sn}$ & $1.50 \mathrm{E}-04$ & 4.10E-01 & $4.30 E+05$ & $9.54 E-07$ \\
\hline${ }^{126} \mathrm{Sn}$ & $7.70 \mathrm{E}-04$ & $2.11 \mathrm{E}+00$ & $3.30 E+05$ & $6.38 \mathrm{E}-06$ \\
\hline${ }^{124} \mathrm{Sb}$ & $4.20 \mathrm{E}-08$ & $1.15 \mathrm{E}-04$ & $1.30 E+06$ & $8.84 \mathrm{E}-11$ \\
\hline${ }^{128} \mathrm{Sb}$ & $7.80 \mathrm{E}-05$ & $2.13 \mathrm{E}-01$ & $2.50 \mathrm{E}+06$ & $8.53 E-08$ \\
\hline
\end{tabular}


WHC-SD-WM-TI-781, Rev. 0

\begin{tabular}{|c|c|c|c|c|}
\hline Isotope & $\mathrm{Ci} / \mathrm{kg}$ & Ci/Large Canister & Cat. 2 To & $\begin{array}{c}\text { Ratio (Ci of } \\
\text { Isotope/Cat. } 2 \text { TQ) }\end{array}$ \\
\hline${ }^{126 m} \mathrm{sb}$ & $5.50 \mathrm{E}-04$ & $1.50 \mathrm{E}+00$ & $4.30 \mathrm{E}+05$ & $3.50 \mathrm{E}-06$ \\
\hline${ }^{125} \mathrm{Sb}$ & $1.60 \mathrm{E}-01$ & $4.38 E+02$ & $4.30 E+05$ & $1.02 E-03$ \\
\hline${ }^{125 \mathrm{~mm}} \mathrm{Te}$ & $4.80 E-02$ & $1,31 E+02$ & $4.30 E+05$ & $3.05 \mathrm{E}-04$ \\
\hline${ }^{129} I$ & $1.50 E-06$ & 4.10E-03 & $4.30 E+05$ & $9.54 \mathrm{E}-09$ \\
\hline${ }^{194} \mathrm{Cs}$ & $1.10 E-01$ & $3.01 E+02$ & $6.00 E+04$ & $5.01 E-03$ \\
\hline${ }^{135} \mathrm{Cs}$ & $4.80 E-04$ & $1.31 E+00$ & $4.30 E+05$ & $3.05 E-06$ \\
\hline${ }^{137} \mathrm{Cs}$ & $4.80 E+01$ & $1.31 E+05$ & $8.90 E+04$ & $1.48 \mathrm{E}+00$ \\
\hline${ }^{137 \mathrm{maa}}$ & $4.80 E+01$ & $1.31 \mathrm{E}+05$ & $x x$ & $x x$ \\
\hline${ }^{144} \mathrm{Ce}$ & $1.60 \mathrm{E}-03$ & $4.38 E+00$ & $8.20 \mathrm{E}+04$ & $5.34 E-05$ \\
\hline${ }^{144} \mathrm{Pr}$ & $1.60 E-03$ & $4.38 E+00$ & $x x$ & $x x$ \\
\hline${ }^{144 m \mathrm{Pr}}$ & $1.60 \mathrm{E}-06$ & $4.38 \mathrm{E}-03$ & $2.50 E+06$ & $1.75 \mathrm{E}-09$ \\
\hline${ }^{197} \mathrm{Pm}$ & $2.60 \mathrm{E}+00$ & $7.11 \mathrm{E}+03$ & $8.40 E+05$ & 8.47E-03 \\
\hline${ }^{151} \mathrm{Sm}$ & $1.50 E+00$ & 4.10E+03 & $9.90 E+05$ & $4.14 \mathrm{E}-03$ \\
\hline${ }^{152} \mathrm{EU}$ & $2.40 \mathrm{E}-03$ & $6.56 \mathrm{E}+00$ & $1.30 E+05$ & $5.05 \mathrm{E}-05$ \\
\hline${ }^{154} \mathrm{EU}$ & $2.60 \mathrm{E}-01$ & $7.11 \mathrm{E}+02$ & $1.10 E+05$ & $6.46 E-03$ \\
\hline${ }^{155} \mathrm{Eu}$ & $1.50 \mathrm{E}-01$ & 4. $10 E+02$ & $7.30 \mathrm{E}+05$ & $5.62 \mathrm{E}-04$ \\
\hline${ }^{234} \mathrm{U}$ & $1.20 \mathrm{E}-05$ & $3.28 \mathrm{E}-02$ & $2.20 \mathrm{E}+02$ & $1.49 E-04$ \\
\hline${ }^{235} \mathrm{U}$ & $5.20 \mathrm{E}-07$ & $1.42 \mathrm{E}-03$ & $2.40 \mathrm{E}+02$ & 5.93E-06 \\
\hline${ }^{236} \mathrm{U}$ & $1.30 E-06$ & $3.56 \mathrm{E}-03$ & $5.50 E+01$ & $6.46 \mathrm{E}-05$ \\
\hline${ }^{230} \mathrm{U}$ & $9.40 \mathrm{E}-06$ & $2.57 \mathrm{E}-02$ & $2.40 \mathrm{E}+02$ & $1.07 \mathrm{E}-04$ \\
\hline${ }^{237} \mathrm{~Np}$ & $3.70 \mathrm{E}-04$ & $1.01 \mathrm{E}+00$ & $5.80 E+01$ & $1.74 \mathrm{E}-02$ \\
\hline${ }^{230} \mathrm{Pu}$ & $1.80 E-03$ & $4.92 \mathrm{E}+00$ & $6.20 \mathrm{E}+01$ & 7.94E-02 \\
\hline${ }^{239} \mathrm{Pu}$ & $1.50 \mathrm{E}-02$ & 4.10E+01 & $5.60 E+01$ & $7.33 \mathrm{E}-01$ \\
\hline${ }^{240} \mathrm{Pu}$ & $4.20 E-03$ & $1.15 \mathrm{E}+01$ & $5.50 \mathrm{E}+01$ & $2.09 \mathrm{E}-01$ \\
\hline${ }^{241} \mathrm{Pu}_{\mathrm{H}}$ & $1.10 E-01$ & $3.01 E+02$ & $2.90 \mathrm{E}+03$ & $1.04 \mathrm{E}-01$ \\
\hline${ }^{2+2} P_{U}$ & $1.10 E-06$ & $3.01 E-03$ & $5.50 \mathrm{E}+01$ & $5.47 E-05$ \\
\hline${ }^{241} \mathrm{Am}$ & $6.90 \mathrm{E}-01$ & 1. $89 E+03$ & $5.50 \mathrm{E}+01$ & $3.43 E+01$ \\
\hline${ }^{242} \mathrm{Am}$ & 5.00E-04 & $1.37 \mathrm{E}+00$ & $4.30 E+05$ & $3.18 \mathrm{E}-06$ \\
\hline${ }^{242 m} \mathrm{Am}$ & $5.20 E-04$ & $1.42 E+00$ & $5.60 \mathrm{E}+01$ & $2.54 E-02$ \\
\hline${ }^{242} \mathrm{Am}$ & $8.10 E-05$ & $2.22 E-01$ & $5.50 E+01$ & 4. $.03 \mathrm{E}-03$ \\
\hline${ }^{242} \mathrm{Cm}$ & $6.00 E-04$ & $1.64 E+00$ & $1.70 E+03$ & $9.65 E-04$ \\
\hline${ }^{244} \mathrm{Cm}$ & $1.50 \mathrm{E}-02$ & $4.10 E+01$ & $5.50 E+01$ & $7.46 E-01$ \\
\hline & & & Sum of Ratios & $4.39 E+01$ \\
\hline
\end{tabular}

$\begin{array}{lll}\text { CAT } & = & \text { category } \\ \text { TQ } & = & \text { Threshold Quantity } \\ X X & = & \text { Isotope's TQ included with parent. }\end{array}$


From Table 5-1, one large canister represents 43.9 times the TQ value for a Hazard Category 2 facility, or 87.8 times the TQ per tube. With 452 large canisters in a vault, this would represent 19,843 times the Hazard Category TQ 2 value.

This represents a substantial increase in quantities of radionuclide inventory from the storage of the glass canisters and cesium containers in the CSB, compared to that of SNF $(15,700$ times the TQ 2 value

[WHC-SD-SNF-HC-001]), although the final hazard categorization of the CSB may not change. To be a Hazard Category 1 facility requires the facility to be a Category A reactor or be designated as Hazard Category 1 by the PSO.

Therefore, the final hazard category document for the CSB would need to be up-dated to include the glass canisters and cesium containers and submitted to DOE for review and approval.

\subsection{CESIUM CONTAINER EVALUATION}

The cesium container was evaluated for benefits of double-containment during transfer and storage of the HLW.

\subsection{CONTAINER TRANSPORTATION}

The requirements for safely packaging ion exchange resin contaminated with cesium-137 for transport are similar to storage requirements. Packaging design for transport involves consideration of the potential dynamic stresses that will affect the package. Furthermore, transport operations involve the handling of the package in the environment without the protection of a facility. Because transportation is a transient operation, however, many storage requirements for packaging will be more restrictive than the transport requirements, including provisions for pressurization.

The transport safety of the cesium containers depends on the shielding and containment capabilities of the transport cask. The transport cask will provide the primary containment boundary, so the benefit of having a doubly encapsulated cesium container is minimal for transport. Because neither of the two cesium containers will be designed to withstand transport accident conditions, the safety analysis for packaging must rely on the assumption that if one container undergoes catastrophic failure, then the second container will also fail. Furthermore, the consequences of a leak in the cesium container during transport are insignificant compared to such an event in the CSB, since the transport cask is designed to withstand the entire spectrum of transportation accidents. If the interior of the transport cask is inadvertently contaminated, the cask can be relocated to a suitable facility for decontamination.

The shielding provided by the transport cask must be sufficient to maintain the dose rate below $100 \mathrm{mr} / \mathrm{hr}$ on the cask surface and $10 \mathrm{mr} / \mathrm{hr}$ at 2 meters. This shielding must be sufficient to prevent the dose rate at 1 meter 


$$
\text { WHC-SD-WM-TI-781, Rev. } 0
$$

from exceeding $1 \mathrm{rem} / \mathrm{hr}$ when the transport cask is subjected to credible transportation accident conditions.

The credible accidents were identified based on the extent of the shipping campaign and the design of the transport cask. Typical credible accidents include a collision or drop during transport.

The design of the transport cask must be adequate to maintain the containment boundary when subjected to normal transport conditions and credible transportation accident conditions.

The containment and shielding integrity of the transport cask must be protected against the effects of decay heat and pressurization.

The additional operational controls that may be determined appropriate for the transport of the cesium container include the imposition of speed limits for the transport vehicle and restrictions on transport during bad weather.

The requirements governing the packaging and transportation of radioactive material onsite are provided in WHC-CM-2-14, Hazardous Material Packaging and Shipping.

\subsection{CONTAINER STORAGE}

The following is an evaluation of the safety benefits and tradeoffs that may be realized by the double containment of the cesium ion exchange resin containers (cesium containers). A double-containment container may provide greater safety for the handling of the ion exchange resin during loading, transport, unloading, and storage; however, some important considerations must be addressed before a decision is rendered. It is assumed that a double containment design can be developed that will maintain the same outer dimensions and meet the handling requirements for the CSB.

The principal safety considerations of single verses double containment are related to the effects on the potential accidents that have been postulated in evaluating the safety of the CSB handling and storage of the containers. There are five possible means of container breach postulated in the evaluation that could lead to a release of radioactive cesium from the cesium containers: mechanical damage, corrosion, pressurization, overheating and explosion. The impact of double containment on each of these accident initiators is discussed below.

\subsubsection{Mechanical Damage}

Most of the postulated accidents that contribute to the overall risk associated with the handling and storage of the cesium containers are mechanical damage events. Damage events have been considered that result from dropping a container, mishandling a container, and collisions involving a container. There is also a postulated event that involves the interaction and 
rupture of two containers. The mechanical strength of the containers is a key parameter that will effect their resistance to damage, and the provision of double containment is expected to contribute some amount of additional strength to the package. The double containment will also add weight to the package and may complicate handling during transport and storage operations. The seismic performance of a heavier container may also be different than a single container. The single containment packages as specified have a maximum gross weight near $300 \mathrm{~kg}$ (650 1bs), and a double containment package could be double that weight or $600 \mathrm{~kg}(1,300 \mathrm{lbs})$. The mechanical forces associated with most drop scenarios of containers are expected to rupture both confinements. Design of a double containment package could address each of these considerations, and perhaps a robust secondary confinement could be provided that would increase the probability of the container surviving a drop accident or seismic event. However, a few risk dominant accidents would still be postulated for the double containment package and require consideration. The evaluation of these accidents will likely show only a slight reduction in the overall risk as a result of a lower probability of damage and/or slight reduction in the amount of material released.

\subsubsection{Corrosion}

It has been postulated that material incompatibilities between the package contents and its materials of construction could lead to corrosion and a breach of the container. The container material has been specified to be stainless steel and the package contents is expected to always be cesium ion exchange resin. Abnormal events include the retention of up to $10 \%$ water to the containers, which could lead to other safety concerns but probably not corrosion. The addition of acids or other unanticipated and incompatible materials is extremely unlikely, but could lead to a corrosion failure of the container.

The application of a double confinement container would affect the corrosion performance of the package, but probably only to delay the failure and release; that is, to increase the time to failure by increasing the amount of material that must corrode before a release occurs. Since a corrosion failure is not expected to result in a catastrophic release of material, this event is less severe than most postulated mechanical failures, and is therefore not a risk dominant event. Development of a double containment package for cesium ion exchange resin does not seem to provide much safety benefit for corrosion resistance.

\subsubsection{Pressurization}

The presence of water or other unexpected and incompatible materials within a container has been postulated as a means to pressurize the package. The generation of gas or steam could result in the stressing of the container and eventual rupture and release of the radioactive material contents. The application of double containment is again expected to provide only a small benefit. 
WHC-SD-WM-TI-781, Rev. 0

The presence of a secondary containment during a pressurization failure of the primary containment may mitigate or prevent the release of material from the package, but the cause of the pressurization may still be present and, without detection and correction, would continue and also pressurize and fail the secondary containment. Unless the package is designed with special detection features or rupture disks, it is not likely that double containment will offer any significant reduction in the safety risk from pressurization of cesium containers.

\subsubsection{Overheating}

The loss of convective cooling or the presence of an unexpectedly large heat source within a container has been postulated as a means to overheat a cesium container and lead to melting or a pressurized rupture. The presence of double containment may help to delay the release from such failures and may even prevent container rupture; but if not specifically designed for such conditions, double containment may exacerbate the overheating problem by degrading heat transfer. Overheating accidents have been considered for the CSB and are a concern for the HLW glass canisters as well. Since the contribution to the overall safety risk from overheating of cesium containers is small, the benefit of double containment for the prevention or mitigation of this event is deemed small.

\subsubsection{Explosion}

The generation of hydrogen by the radiolysis of water has been postulated as an initiator of either an internal or an external explosion leading to the release of radioactive materials. Water inside a cesium container is an abnormal event. Since the ion exchange resin is packaged in air and since the radiolys is of water produces both hydrogen and oxygen, the generation of hydrogen might lead to the development of a detonable mixture. The free volume inside the container is small and but no detailed analysis of the explosive power of the worst case mixture has been completed. Similarly, the presence of water in a storage tube has been postulated as a source of radiolytic hydrogen generation for both cesium containers and glass canisters. An explosion under these conditions might implode and rupture a container.

The application of a double container to these scenarios seems to offer some limited benefit. The detonation of a hydrogen mixture within the primary containment of a double containment package may result in a reduction in the amount of radioactive material that is postulated to be released. If strong enough, the secondary containment may even sustain the explosion and rupture of the inner primary containment. Conversely, the secondary containment may offer an added gas volume that would increase the available oxygen and lead to an even greater volume of detonable gas and a more severe accident. For externaliy initiated explosions, the secondary containment seems to offer two effects. The increased shielding and distance between the radiation source and the water may decrease the rate of hydrogen generation by radiolysis, which may also decrease the probability of a detonation. The secondary 
WHC-SD-WM-TI-781, Rev. 0

containment may also offer greater resistance to damage of the inner containment by an external explosion.

\subsubsection{Summary}

Each of the postulated accident initiators leading to the release of radioactive material from the ion exchange containers was considered and the effects of both single and double containment packaging was evaluated to estimate the safety benefit. Table 6-1 compares the expected benefits and disadvantages of double containment for each accident type and assigns a subjective score to aid quantitative judgement.

The overall safety risk associated with the handling and storage of cesium containers may be improved by the application of double containment, but the benefit may be small as compared to the already low risk of the container storage operation. Several safety-class/safety-significant structures, systems and components are included in the design of the CSB to assure the low risk of SNF and HLW glass canister handling and storage. The potential consequences from SNF accidents is roughly 4 times greater than that of cesium container accidents for the same source term mass (note that the unit gram dose for SNF is $4.3 \times 10^{5}$ rem and for the cesium it is $1.1 \times 10^{5}$ rem). The CSB safety risk is dominated by SNF and HLW glass canister handling. The addition of a double confinement container for cesium containers appears to be of small benefit to reduce risk. A rigorous costbenefit analysis and risk assessment may be necessary to provide definitive evidence, but the subjective evaluation provided here suggests that the added safety benefit of double containment is small and does not justify the required effort. 
Table 6-1. Summary of Double Containment Evaluation.

\begin{tabular}{|c|c|c|c|}
\hline TYPE & ADVANIAGES & DISADVANTAGES & SCORE \\
\hline $\begin{array}{l}\text { Mechenical } \\
\text { impact }\end{array}$ & $\begin{array}{l}\text { Mechanical strength, } \\
\text { increased resistance } \\
\text { to some impacts, might } \\
\text { hold up release if } \\
\text { inner container failed } \\
\text { first }\end{array}$ & $\begin{array}{l}\text { Increased weight and } \\
\text { handling difficulties }\end{array}$ & $+2,-2=0$ \\
\hline Corrosion & $\begin{array}{l}\text { Increased time to } \\
\text { fail, hold up of } \\
\text { release }\end{array}$ & $\begin{array}{l}\text { Without detection, second } \\
\text { barrier will likely also } \\
\text { fail }\end{array}$ & $+1,-1=0$ \\
\hline Pressurization & $\begin{array}{l}\text { Larger total volume to } \\
\text { pressurize }\end{array}$ & $\begin{array}{l}\text { Without detection, second } \\
\text { barrier will likely also } \\
\text { fail }\end{array}$ & $+1,-1=0$ \\
\hline overheating & $\begin{array}{l}\text { Increased heat } \\
\text { capacity, mitigation } \\
\text { of release }\end{array}$ & $\begin{array}{l}\text { Decreased thermal } \\
\text { conductivity }\end{array}$ & $+1,-1=0$ \\
\hline Explosion & $\begin{array}{l}\text { May survive some small } \\
\text { explosions }\end{array}$ & $\begin{array}{l}\text { May increase explosive gas } \\
\text { volume }\end{array}$ & $+2,-1=+1$ \\
\hline General & $\begin{array}{l}\text { Potential for failure } \\
\text { detection before } \\
\text { release }\end{array}$ & Design cost, time delay & $+1,-2=-1$ \\
\hline
\end{tabular}

\subsection{NRC EQUIVALENCY REVIEW}

The purposes of this NRC evaluation are: 1) a preliminary review of the SNF Project nuclear safety equivalency NRC comparison to the proposed HLW storage in CSB, and 2) as a result of this review and evaluation and the conclusions drawn, identify any actions for consideration that may be necessary to demonstrate nuclear safety equivalence for the preliminary design.

The review basis was provided from WHC-SD-SNF-DB-002, Spent Nuclear Fuel Project Path Forward, Nuclear Safety Equivalency to Comparable NRC-Licensed Facilities. The review basis was presented in four principal subgroups: 1) parts, sections and appendices determined to be not applicable; 2) NRC regulations accommodated by WHC site-wide programs; 3 ) NRC regulations potentially applicable to new SNF Project facilities; and 4) NRC guidance potentially applicable to new SNF Project facilities.

\subsection{DESIGN AND CONSTRUCTION MEASURES}

In addition, NRC guidance that may have direct application to CSB Project design and construction activities, was reviewed as a prudent step in implementing the Policy's objectives. In accordance with the Policy, the scope of potentially applicable NRC technical requirements are the design and 
WHC-SD-WM-TI-781, Rev. 0

construction measures (as opposed to also including preoperational or operational measures) mandated by the NRC regulations, for the purposes of this evaluation, Title 10 Code of Federal Regulations, Parts 0 through 199 , revised as of January 1,1995 . These requirements which are identified in WHC-SD-SNF-DB-003, Spent Nuclear Fuel Project Path Forward, Additional NRC Requirements, apply to the CSB.

\subsubsection{Results}

The NRC requirements consolidated into 29 items in WHC-SD-SNF-003, apply to the CSB HLW transfer and storage. All items comply with NRC regulations with the exception of the design earthquake, which is being implemented in a manner that establishes equivalence in safety, as opposed to direct equivalence to the regulation. The seismic issue was presented in detail in a separate WHC document, WHC-SD-SNF-DB-004, Spent Nuclear Fue7 Project Seismic Design Criteria, Nuclear Regulatory Commission Equivalency Evaluation Report, which is based upon: 1) the current CSB design meeting both the DOE and NRC safety goals, and 2) the overall seismic risk is lower than the risk associated with licensed nuclear power plants.

The review basis information was provided from WHC-SD-SNF-DB-003, Table 1, which identifies the responsible discipline(s) for implementation of the requirements (e.g., civil structural and mechanical) to help facilitate value to the end user. Where the table includes a reference(s), this does not imply that the identified additional NRC requirement(s) and related DOE requirements necessarily satisfy the requirements of the reference(s), or even that the SNF Project Path Forward must satisfy the requirements of the reference(s). It is simply a notation as to where the basic issue is raised, and where the reader may refer to in WHC-SD-SNF-DB-002, and NRC regulations and guidance for related information.

\subsection{CONCLUSIONS}

In the comparison of $\mathrm{DOE}$ and $\mathrm{NRC}$ requirements relevant to the design and construction of CSB facility HLW transfer and storage, a number of differences were identified in WHC-SD-SNF-DB-002. Where differences exist, the NRC requirements for the most part were either more conservative or require the preparation of additional documentation (e.g., as part of a safety analysis report).

In regards to establishing nuclear safety equivalency, Actions for Consideration were identified for meaningful differences where existing SNF Project Path Forward requirements need to be enhanced. For ease of identification, all differences, where Actions for Consideration were identified, were consolidated into WHC-SD-SNF-DB-002, Table 2. The more important of these items, i.e., may have substantive project impacts, are identified below with their corresponding regulation or guidance number and a brief caption of the item. This list was compiled based on the current preliminary safety class equipment required for the CSB HLW transfers and 
WHC-SD-WM-TI-781, Rev. 0

storage, and need for HLW transfer and storage to comply with the SNF Project requirements.

- Section 72.3, Definitions (definition of structures, systems and components [SSCs] important to safety embraces additional Safety Class 1 SSCs).

- Section 72.92, Design basis external natural events, and $\$ 72.102$, Geologic and seismological characteristics (more conservative seismic design criteria).

- Section 72.122 , Overall requirements (inclusion of sharing of common utilities, tornado and tornado missiles).

- SRP 9.1.2, Spent Fuel Storage (use of a $k_{\text {eff }}$ criticality safety limit of $0.95)$.

A detailed NRC equivalency review for the HLW storage should be conducted to verify these conclusions and establish the baseline NRC equivalency requirements for the addition of HLW storage in the CSB.

Also, equivalency was established for the most part by DOE orders and in some instances by WHC procedures and instructions in WHC-SD-SNF-DB-002. If the SNF Project takes steps to acquire waivers for some of the DOE orders used to establish nuclear safety equivalency, or if relevant DOE orders or WHC procedures and instructions are revised or canceled, a number of the conclusions regarding nuclear safety equivalency in this evaluation could be nullified.

Future detailed NRC equivalency review may provide additional requirements for handling and storage of HLW in the CSB.

\subsection{SAFETY ANALYSIS REQUIREMENTS}

Safety analysis requirements for the safe storage of HLW in the CSB will be determined by a safety review which will address similar questions as defined in WHC-IP-0842, TWRS Administration, Unreviewed Safety Questions, and the possible revision of the CSB facility hazard classification, WHC-SD-SNF-HC-007. Deviations from the safety basis will require additional safety analysis and revision to WHC-SD-SNF-RPT-004, Canister Storage Building Safety Analysis Report - Phase 2 Safety Analysis Documentation Supporting Canister Storage Building Subsurface Construction and Fabrication of Tubes, Multi-Canister Overpack Handling Machine and Receiving Crane. This forms the basis for the extent of safety analysis for the storage of HLW in the CSB.

Based on the preliminary accident analysis results from Sections 4.0 and 5.0 , only following items would require additional analysis for storage of HLW: 1) the consequences and probabilities of the accidents previousiy evaluated in WHC-SD-SNF-RPT-004 would increase, 2) a new accident for shearing the canisters would be added to the accidents in WHC-SD-SNF-RPT-004, and the 
additional hazardous material may revise the hazard category. These items will require additional safety analyses and revision of the WHC-SD-SNF-RPT-004 and WHC-SD-SNF-HC-007 (Kummerer 1995).

It is recommended that for future safety analysis, during conceptual design, a formal hazards identification/evaluation should be performed of the entire HLW container handling and storage process. Verification and validation of the inventory assumptions (radionuclide content and physical form) used for accident analys is should be performed. This is particularly important for the physical form of the cesium ion exchange resin. This evaluation assumed, for normal conditions, a dry product with a relatively smal1 percentage of respirable particles $(0.1 \%)$. If the resin is ground up or somehow reduced to small particles during the drying process, this will potentially change the accident analysis results. The safety equipment list should be verified, to make sure that the appropriate CSB systems are incorporated. Furthermore, a detailed review of facility modifications should be performed, particularly the potential need for replacement of the MHM casks. A structural analysis may need to be performed to determine the potential effects of dropping the new MHM cask on the safety-class vault roof, either during construction or a seismic event. A preliminary hazard categorization must be documented. Because the design of the facility and process is in a relatively early stage, no attempt was made to evaluate accident frequencies. In order to evaluate risk, some sort of frequency determination will need to be performed. A set of administrative controls and TSR/OSR must be developed to assure that the assumptions in the safety analysis are implemented in the design and operation of the facility. In particular, the appropriate surveillance program for containers in interim storage must be developed. This report assumes that some periodic monitoring of the storage wells will be performed by a surveillance program.

The cost and schedule for the proposed safety analysis activities are provided in Table 8-1.

Table 8-1. Resources and Schedule.

\begin{tabular}{|c|c|c|}
\hline ACTIVITY & FTE & DURATION \\
\hline Hazard category revision & $1.5 \mathrm{FTE} /$ Mo. & 2 Months \\
\hline Hazard analysis & $2.5 \mathrm{FTE} /$ Mo. & 1 Month \\
\hline Safety analysis & $3.0 \mathrm{FTE} /$ Mo. & 4 Months \\
\hline FSAR revision & $2.5 \mathrm{FTE} /$ Mo. & 3 Months \\
\hline DOE review & $1.5 \mathrm{FTE} /$ Mo. & 3 Months \\
\hline
\end{tabular}

$\mathrm{DOE}=$ U.S. Department of Energy

FSAR = Final Safety Analysis Report

FTE = Full-time Equivalent 


\subsection{REFERENCES}

D0E-RL, 1995, Hanford Emergency Response Plan, DOE/RL-94-02, U.S. Department of Energy, Richland Operations Office, Richland, Washington.

DOE, 1992, Hazard Categorization and Accident Analysis Techniques for Compliance with DOE Order 5480.23, Nuclear Safety Analysis Reports, DOE Standard 1027-92, U.S. Department of Energy, Washington, D.C.

EBASCO/BNFL, 1994, Initial Pretreatment Module - Cesium Demonstration Unit Preliminary Safety Evaluation, February 28, 1994.

EPA, 1988, Limiting Values of Radionuclide Intake And Air Concentration and Dose Conversion Factors For Inhalation, Submersion, And Ingestion, EPA-520/1-88-020, U.S. Environmental Protection Agency, Washington, D.C.

Farnsworth, R.K., and J. Mishima, 1988, DWPF Canister Impact Testing and Analyses for the Transportation Center, PNL-6379 (UC-70), Pacific Northwest Laboratory, Richland, Washington.

Hey, B. E., 1993a, GXQ Program Users' Guide, WHC-SD-GN-SWD-30002, Rev. 1, Westinghouse Hanford Company, Richland, Washington.

Hey, B. E., 1993b, GXQ Program Verification and Validation, WHC-SD-GN-SWD-30003, Rev. 0, Westinghouse Hanford Company, Richland, Washington.

ICRP, 1975, Reference Man: Anatomical, Physiological, and Metabolic Characteristics, Publication 23, International Commission on Radiological Protection, Elmsford, New York.

Jacobs, E. R., 1996, HLW Interim Storage Facility Feasibility Study, (External Letter FRF-016 to R. B. Calmus, WHC) Fluor Daniel, Inc., Richland, Washington.

Kummerer, M., 1995, Hazard Category Analysis for the Canister Storage Building, WHC-SD-SNF-HC-007, Rev. 0, Westinghouse Hanford Company, Richland, Washington.

Mishima, J., 1994, Airborne Release Fractions/Rates and Respirable Fractions/Rates for Nonreactor Nuclear Facilities, DOE-HDBK-3010-94, U.S. Department of Energy, Washington, D.C.

NRC, 1982, Accident Generated Particulate Materials and Their Characteristics -- A Review of Background Information, NUREG/CR-2651, U.S. Nuclear Regulatory Commission, Washington, D.C.

NRC, 1988, Nuclear Fuel Cycle Facility Accident Analysis Handbook, NUREG-1320, U.S. Nuclear Regulatory Commission, Washington, D.C. 
Sellers, E. D., 1996, Hazard Category for the Spent Nuclear Fuel Project Canister Storage Building (CSB) (Letter 95-SFD-250 to President, Westinghouse Hanford Company, January 10), U.S. Department of Energy, Richland Operations office, Richland, Washington.

Sutter, 1983, Aeroso7s Generated by Releases of Pressurized Powders and Solutions in Static Air, NUREG/CR-3093, U.S. Nuclear Regulatory Commission, Washington, D.C.

WHC, 1996, Immobilized High-Level Waste Interim Storage Preliminary Path Forward, WHC-SD-WM-SP-011, Rev. 0, Westinghouse Hanford Company, Richl and, Washington.

WHC-CM-2-14, Hazardous Material Packaging and Shipping, Westinghouse Hanford Company, Richland, Washington.

WHC-CM-4-46, Safety Analysis Manual, Westinghouse Hanford Company, Richland, Washington.

WHC-IP-0842, TWRS Administration, Unreviewed Safety Questions, Westinghouse Hanford Company, Richland, Washington.

WHC-SD-SNF-DB-002, Spent Nuclear Fuel Project Path Forward, Nuclear Safety Equivalency to Comparable NRC-Licensed Facilities, Rev. 2, Westinghouse Hanford Company, Richland, Washington.

WHC-SD-SNF-DB-003, Spent Nuclear Fuel Project Path Forward, Additional NRC Requirements, Rev. 2, Westinghouse Hanford Company, Richland, Washington.

WHC-SD-SNF-DB-004, Spent Nuclear Fuel Project Seismic Design Criteria, Nuclear Regulatory Commission Equivalency Evaluation Report, Westinghouse Hanford Company, Richland, Washington.

WHC-SD-SNF-RPT-004, Canister Storage Building Safety Analysis Report - Phase 2 Safety Analysis Documentation Supporting Canister Storage Building Subsurface Construction and Fabrication of Tubes, Multi-Canister Overpack Handling Machine and Receiving Crane, Rev.2, Westinghouse Hanford Company, Richland Washington. 
DISTRIBUTION SHEET

\begin{tabular}{|c|c|c|c|c|c|}
\hline \multirow{2}{*}{$\begin{array}{l}\text { To } \\
\text { Distribution }\end{array}$} & \multirow{2}{*}{\multicolumn{3}{|c|}{$\begin{array}{l}\text { From } \\
\text { R. J. Kidder }\end{array}$}} & \multicolumn{2}{|l|}{ Page 1 of 1} \\
\hline & & & & \multicolumn{2}{|c|}{ Date $09 / 13 / 96$} \\
\hline \multicolumn{4}{|l|}{ Project Title/Work Order } & \multicolumn{2}{|c|}{ EDT No. 616269} \\
\hline \multicolumn{4}{|c|}{$\begin{array}{l}\text { Canister Storage Building Evaluation of Nuclear Safety for } \\
\text { Solidified High-Level Waste Transfer and Storage, } \\
\text { WHC-SD-WM-TI-781, Rev } 0\end{array}$} & \multicolumn{2}{|l|}{ ECN No. NA } \\
\hline \multicolumn{2}{|l|}{ Name } & $\begin{array}{l}\text { Text } \\
\text { With All } \\
\text { Attach. }\end{array}$ & Text Only & $\begin{array}{l}\text { Attach./ } \\
\text { Appendix } \\
\text { Only }\end{array}$ & $\begin{array}{c}\text { EDT/ECN } \\
\text { Only }\end{array}$ \\
\hline $\begin{array}{l}\text { K. C. Burgard } \\
\text { R. B. Calmus (5) } \\
\text { L. E. Johnson } \\
\text { R. J. Kidder (3) } \\
\text { J. E. Mercado } \\
\text { D. A. Smith } \\
\text { Central Files (2) }\end{array}$ & $\begin{array}{l}\mathrm{H} 5-03 \\
\mathrm{H} 5-27 \\
\mathrm{~A} 2-25 \\
\mathrm{~A} 2-25 \\
\mathrm{G} 1-11 \\
\mathrm{R} 2-11 \\
\mathrm{~A} 3-88\end{array}$ & $\begin{array}{l}x \\
x \\
x \\
x \\
x \\
x \\
x\end{array}$ & & & \\
\hline
\end{tabular}

